Fall 12-8-2021

\title{
Lung Cancer Screening: An Evidence-Based Practice Change Project
}

Robert Bland

University of St. Augustine for Health Sciences, r.bland@usa.edu

DOI: https://doi.org/10.46409/sr.TAOF3477

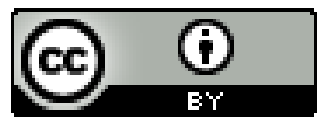

This work is licensed under a Creative Commons Attribution 4.0 License.

Follow this and additional works at: https://soar.usa.edu/scholprojects

Part of the Oncology Commons, Preventive Medicine Commons, Radiology Commons, and the Respiratory Tract Diseases Commons

\section{Recommended Citation}

Bland, R. (2021). Lung Cancer Screening: An Evidence-Based Practice Change Project. [Doctoral project, University of St Augustine for Health Sciences]. SOAR @ USA: Student Scholarly Projects Collection. https://doi.org/10.46409/sr.TAOF3477

This Scholarly Project is brought to you for free and open access by the Student Research at SOAR @ USA. It has been accepted for inclusion in Student Scholarly Projects by an authorized administrator of SOAR @ USA. For more information, please contact soar@usa.edu, erobinson@usa.edu. 


\title{
Lung Cancer Screening: An Evidence-Based Practice Change Project Robert Bland BSN, RN, CCRN-K
}

\author{
School of Nursing, University of St. Augustine for Health Sciences
}

This Manuscript Partially Fulfills the Requirements for the Doctor of Nursing Practice Program and is approved by:

Mary Brann DNP, RN

Debra Stiffler DNP, RN, CEN

December 8, 2021 


\begin{abstract}
Practice Problem: Lung cancer is the leading cause of global cancer deaths and is a significant health issue in the US, claiming more than 155,000 lives each year. Lung cancer screening through low dose computed tomography (LDCT) can reduce lung cancer mortality by 20 percent but unfortunately, lung cancer screening is underutilized.
\end{abstract}

PICOT Question: The PICOT question that guided this project was: in a patient population eligible for LDCT lung screening (P), how does auditing of practice with feedback to the providers (I), compared to not doing the interventions as mentioned above (C), increase LDCT lung cancer screenings in the identified population $(\mathrm{O})$, in an eight-week period $(\mathrm{T})$ ?

Evidence: A thorough literature review was conducted to determine if audit and feedback is an evidence-based strategy for increasing cancer screening rates. The literature review produced ample evidence supporting audit and feedback as an effective strategy for significantly increasing cancer screening rates.

Intervention: A lung cancer screening audit tool with essential elements for determining patient eligibility for LDCT lung cancer screening was created for this project, and the face validity of the audit tool was obtained. During the project's intervention and evaluation phase, each audit tool submitted was analyzed for completeness, and performance feedback was given to the clinic's providers on a weekly basis.

Outcome: Although Chi-Square analysis did not show statistical significance, the number of LDCT lung cancer screening scans nearly doubled during the intervention phase compared to the baseline phase of the project.

Conclusion: The continued usage of the lung cancer screening audit and feedback tool is recommended for increasing the number of LDCT lung cancer screenings. 


\section{Lung Cancer Screening: An Evidence-Based Practice Change Project}

Each year in the US, lung cancer kills more than 155,000 individuals (Kassem \& Laird, 2019). The risk of developing lung cancer is one out of fifteen for men and one out of seventeen for women (American Cancer Society, 2021b). Although annual lung cancer screening can reduce lung cancer mortality rates by $20 \%$, this lifesaving strategy is underutilized (Velez Martinez et al., 2020). The purpose of this paper is to present an evidence-based practice change project to improve lung cancer screening rates at a primary care clinic located in Northeast Florida.

\section{Significance of the Practice Problem}

Lung cancer is a devastating disease and the most frequently diagnosed form of cancer (American College of Chest Physicians, 2020). By 2030, the global lung cancer incidence rate is estimated to reach 2.89 million, a 38 percent increase from the current rate (American College of Chest Physicians, 2020). Lung cancer is the leading cause of global cancer-related deaths (Toumazis et al., 2020). In 2018, lung cancer caused 1.76 million deaths, followed by colorectal $(862,000)$, stomach $(783,000)$, liver $(782,000)$, and breast $(627,000)$ (American College of Chest Physicians, 2020).

Florida's rate of new lung cancer cases is 58 per 100,000 individuals, which is 21 st in the US for new lung cancer cases (American Lung Association, 2020). The demographic stratification of new lung cancer cases in Florida is 24.6 among American Indians, 25.8 among Asian Americans, 37.7 among Latinos, 45.2 among Blacks, and 64.9 among whites (American Lung Association, 2020). Although within the average tier among US states for lung cancer cases, Florida ranks 12th for survival data (American Lung Association, 2020). The county in 
which the project will take place ranks 45th out of the 67 Florida counties for the highest lung cancer death rates (Florida Department of Health, 2019). Until the 1990s, this county had the highest lung cancer rates out of all metropolitan areas in the US (Tousey et al., 1999).

Cancer is the most costly disease in the US and accounts for out-of-pocket expenses that exceed $20 \%$ of the patient's income (Hazell et al., 2020). The economic impact of lung cancer is astronomical. In 2004, lung cancer accounted for $20 \%$ of all cancer-related spending by Medicare and cost over $\$ 4.2$ billion (Jeon et al., 2019). During the initial phases of treatment, patients with lung cancer that receive chemotherapy or radiation incur an average monthly cost between $\$ 4282$ and $\$ 8287$ (Sheehan et al., 2019). The average cost of surgery for lung cancer patients exceeds $\$ 30,000$ during the first month (Sheehan et al., 2019). Recent studies suggest that 52.7 percent of lung cancer survivors experienced significant difficulties living within their current income and had treatment expenses that exceeded $\$ 7000$ per month (Sheehan et al., 2019). The financial burden of lung cancer adversely impacts the patients' quality of life and compliance with their treatment plan (Hazell et al., 2020).

Low-dose computed tomography (LDCT) lung screening is the only recommended diagnostic study for lung cancer among high-risk patients (Center for Disease Control and Prevention $[C D C], 2020)$. Unfortunately, this life-saving screening is underutilized. Less than 12 percent of patients at a high-risk for lung cancer receive annual lung cancer screening (Honey, 2020). According to a recent study, a key reason LDCT lung screening is underutilized is that most physicians are not discussing lung screening with their patients (Huo et al., 2019). The underuse of LDCT lung screening is more of an issue in the Southern US states since these states 
contain more screening-eligible patients yet have fewer primary care physicians per capita (Pham et al., 2020).

\section{PICOT Question}

The population $(\mathrm{P})$, intervention $(\mathrm{I})$, comparison $(\mathrm{C})$, outcome $(\mathrm{O})$, and time $(\mathrm{T})$ question is a useful framework for defining practice questions while establishing proposed solutions (Riva et al., 2012). In a patient population eligible for LDCT lung screening (P), how does auditing practice with feedback to the providers (I), compared to not doing the interventions as mentioned above $(\mathrm{C})$, increase LDCT lung cancer screening in the identified population $(\mathrm{O})$, in an eightweek period (T). Studies show that healthcare providers narrow the gap between their current practice and established benchmarks when they are given performance feedback (N. Ivers, 2012). Audit and feedback is widely used as an evidence-based method for improving patient outcomes (N. Ivers, 2012). In regards to compliance with ordering recommended cancer screening, studies show that audit and feedback has a significantly favorable impact on increasing screening rates (Hwang et al., 2019). The targeted population for this evidence-based project were individuals that met LDCT lung screening criteria as defined by the US Preventive Services Task Force (USPSTF); these criteria include asymptomatic individuals between the ages of 55 and 80 years with a smoking pack-year history greater or equal to 30 years and who have quit smoking within the last 15 years or who currently smoke (Moyer, 2014).

\section{Evidence-Based Practice Framework \& Change Theory}

The Johns Hopkins Nursing Evidence-Based Practice (JHNEBP) Model was used as a framework for this EBP change project. The inquiry phase was predicated upon an organizational needs assessment, which identified a worthwhile practice concern (Dang \& Dearholt, 2018). The practice element of the JHNEBP Model encompasses the nursing process 
and all nursing activities (Dang \& Dearholt, 2018). The practice element is no longer based simply on policies and protocols but must be grounded on evidence (Dang \& Dearholt, 2018). The learning component of the JHNEBP Model, regarding this EBP project incorporated a thorough review of the literature to ensure that the practice change was based on evidence (Dang \& Dearholt, 2018).

Kotter's change model was utilized for this EBP change project. The eight-stage change process posited by Kotter is an effective method for facilitating organizational transformation (Pollack \& Pollack, 2015). The first stage of Kotter's change model is to create a sense of urgency; failure to do so is the most critical error when seeking organizational change (Pollack \& Pollack, 2015). Data was presented to the organization that showed missed lung screening opportunities while depicting the benefits of LDCT lung screening, and how it bolsters the organization's vision. This was critical step in the project since communicating the vision of change promotes visibility within the organization for the desired change (Pollack \& Pollack, 2015). During the project's planning phase, stakeholders were identified, and a coalition for planning and implementing the change was established in accord to Kotter's change process (Pollack \& Pollack, 2015). The final phase of this project, according to Kotter's change model was to ensure that the change became sustainably embedded into the organization's culture (Pollack \& Pollack, 2015).

\section{Evidence Search Strategy}

A thorough literature search was conducted to assess the effectiveness and validity of the proposed intervention. The literature search utilized multiple databases contained within the university's online library search portal. The databases searched were the Cumulative Index to 
Nursing and Allied Health Literature (CINAHL), Academic Search Index, Gale Academic OneFile, Gale OneFile: Health and Medicine, the Directory of Open Access Journals, Supplemental Index, Science Direct, Gale Health and Wellness, Gale In Context: Opposing Viewpoints, Gale Academic OneFile Select, Gale In Context: Science, and Gale General OneFile.

The search terms used for the first search item were "audit and feedback." The filters used for the first search were abstract, peer-reviewed, English language, "find all my search terms", and a date range between 2016 and 2021. In addition, the term "screening" was searched within the abstracts.

\section{Evidence Search Results}

The multiple database literature search yielded 140 articles. Although the multiple databases excluded some duplicates, other duplicates remained. In total, 89 duplicates were excluded, and 50 articles remained for further review. Six of the remaining articles were not primary research and were excluded, leaving 44 articles. The remaining results contained 22 articles that were excluded because although the research pertained to audit and feedback but the studies did not apply these interventions for improving health screening. The 22 remaining articles contained nine articles that were irrelevant to audit and feedback as an intervention. Three of the remaining 13 articles were excluded because audit and feedback was directed at the patient and not the healthcare providers. After exclusions, the final number of articles selected was 10. A summary of the literature search, exclusions, and selections is shown in Figure 1. The John Hopkins Nursing Evidence-Based Practice (JHNEBP) model and its Evidence Level and Quality Guide was used to appraise the level of evidence and quality of the selected 
literature. The JHNEBP model helps nurses incorporate the most up-to-date research findings into nursing practice (D. Dang \& Dearholt, 2017). Table 1 shows the summary of the primary research evidence. Five of the selected articles were quasi-experimental and included quality improvement studies; of these five articles, three were level II with low to good quality. The remaining three quasi-experimental articles were level III and the evidence was low to good quality. Seven articles were retrospective and prospective cohort studies; of these studies, one was a level 1 randomized control trial (RCT) with high quality evidence and a statistically significant sample size. Three of the retrospective and prospective studies had level II evidence; each of these had good quality findings.

\section{Themes with Practice Recommendations}

Numerous studies suggest that audit and feedback can be an effective intervention for improving professional behaviors (Ivers, 2012). Ivers' monumental work on audit and feedback showed that improvement in professional compliance through this intervention achieved a median gain of 4.3\% among 82 comparisons within 49 studies (Ivers, 2012). Individual behavior change theories posit that audit and feedback reveal areas for improvement that are otherwise unknown to individuals (Ivers, 2012).

A review of the literature specific to the PICOT question revealed several functional themes for improving preventive screening. First, PCPs are underutilizing the recommended preventative screening for eligible patients (Baxter et al., 2017; Feldman et al., 2017; HughesCarter \& Hoebeke, 2016; Jonah et al., 2017; Singh et al., 2021). Huges-Carter \& Hoebeke (2016) found that only 0 to 43 percent of patients seen at the primary care clinic studied received recommended diabetic kidney disease screening. Feldman et al. (2017) showed that over half of 
the participants did not receive the recommended baseline screenings for colorectal and breast cancer. Jonah et al. (2017) showed that a third of patients failed to obtain preventive cancer screening.

The second and crucial theme discovered within the literature was that audit and feedback is an evidence-based and effective intervention for improving preventative screening rates (Baxter et al., 2017; Feldman et al., 2017; Hughes-Carter \& Hoebeke, 2016; Hwang et al., 2019; Jonah et al., 2017; Rohweder et al., 2019; Singh et al., 2021; Weiss et al., 2018). The randomized control trial by Hwang et al. (2019) included 96 providers and 6363 patient participants; this study showed that an audit and feedback intervention increased cervical cancer screening from $65.3 \%$ to $77.7 \%$ and increased colorectal cancer screening from $64.6 \%$ to $72.5 \%$. Jonah et al. (2017) utilized an audit and feedback intervention for 7866 PCPs for colorectal screening, 7833 PCPs for breast screening, and 7852 PCPs for cervical cancer screening. Patients of physicians who received regular audit and feedback on preventive screening practices were significantly more likely to receive recommended cancer screening (Jonah et al., 2017). In a study of PCPs that served more than 31,000 patients, audit and feedback increased colorectal cancer screening by a weighted average of $8.0 \%$ (Rohweder et al., 2019). Providing a large physician group that treats more than 35,000 patients annually with audit and feedback alerts significantly increased cancer screening rates (Feldman et al., 2017). This study experienced an increase in cervical cancer screening by $11 \%(\mathrm{p}<0.05)$, breast cancer screening by $9 \%(\mathrm{p}<0.05)$, and colorectal cancer screening by $11 \%$ (p<0.05) (Feldman et al., 2017).

Another theme repeated within the literature for audit and feedback is that feedback specific to providers can increase positive practice behaviors (Feldman et al., 2017; Hwang et al., 
2019; Weiss et al., 2018). Provider-specific feedback on preventative screening practices was an essential component of the statistically successful audit and feedback study by Wiess et al. (2018). Preventative cancer screening data on overdue patients was provided to each physician participant in the study by Feldman et al. (2017). In this study, physicians were sent electronic lists of their patients overdue for screening and were given an opportunity to send reminders to the respective patients (Feldman et al., 2017). The study by Hwang et al. (2019) concluded that sustainability for a successful audit and feedback program for improving cancer screening is more likely when the feedback is specific to each provider.

The last theme discovered from the literature on audit and feedback was that providing peer comparison data to providers may improve preventative screening rates (Feldman et al., 2017; Hwang et al., 2019; Jonah et al., 2017; Rohweder et al., 2019; Weiss et al., 2018). Provider participants in the study by Rohweder et al. (2019) expressed that providing audit and feedback with peer comparison facilitates a healthy competition towards improved performance. Jonah et al. (2017) incorporated peer comparison in their study as an essential component of audit and feedback. Feldman et al. (2017) designed their study for increasing colorectal screening to include peer comparison of providers within their clinic and in the other clinics in their health system.

\section{Practice Recommendations}

The literature clarified that a gap existed between preventative screening recommendations and preventative screening practices (Baxter et al., 2017; Feldman et al., 2017; Hughes-Carter \& Hoebeke, 2016; Jonah et al., 2017). Multiple studies within numerous practice settings concluded that audit and feedback is an effective intervention for statistically improving 
cancer screening rates (Baxter et al., 2017; Feldman et al., 2017; Hwang et al., 2019; Jonah et al., 2017; Rohweder et al., 2019). Effective audit and feedback interventions include providerspecific feedback, and peer comparison has been shown to create a sense of healthy competition among providers and improve screening rates (Feldman et al., 2017; Hwang et al., 2019;

Rohweder et al., 2019; Weiss et al., 2018).

The PICOT question is, in a patient population eligible for LDCT lung screening $(\mathrm{P})$, how does auditing of practice with feedback to the providers (I), compared to not doing the interventions as mentioned above (C), increase LDCT lung cancer screening in the identified population $(\mathrm{O})$, in an eight-week period $(\mathrm{T})$. The practice recommendation for improving lung cancer screening was to establish an audit and feedback program that was provider-specific and contained peer comparisons.

\section{Setting, Stakeholders, and Systems Change}

This DNP scholarly project occured within a primary care clinic affiliated with one of the health system's community hospitals. The overarching health system is one of the largest in the US, with 180 hospitals and care sites within 21 states. The mission of the primary care clinic is that of the hospital: "above all else, we are committed to the care and improvement of human life". The vision of the hospital is "to be an excellent place for employees to work, and an excellent place for physicians to practice medicine, resulting in an excellent place for patients to receive care." The primary care clinic is one of four clinics affiliated with the main hospital, located in Florida. The health system is for-profit and has an organizational culture that is highly driven by metrics and financial performance. The primary care clinic staff included six primary 
care physicians, an office manager, medical assistants, system-level care coordinators, a systemslevel director, and a systems-level executive director.

The inclusion criteria for patient participants for this project was identified according to the US Preventative Services Task Force (USPSTF) 2004 recommendations for LDCT lung screening eligibility. Although the USPSTF recommendations for LDCT lung screening was modified during the writing of this project's proposal (US Preventative Task Force, 2021), the 2004 recommendations will be used since reimbursement is currently based on the 2004 guidelines. The participants were patients who were current smokers or had a history of smoking and were ages 55 to 80 years (Moyer, 2014). The setting for the project was in a primary care clinic that serves the residents within and around its respective zip code. The estimated population within the zip code is 38,231 , had a median age of 37.3 years, and an average household income of $\$ 53,988$ (CDX Technologies, n.d.). Deaths from lung cancer within the clinic's zip code were among the highest in the county; this population reported 85 lung cancer attributable deaths between 2015 and 2019 (Florida Department of Health, n.d.).

The organizational need for this DNP project was determined by corporate benchmarks within the health system, coupled with local demographic data respective to smoking and cancer rates. The number of LDCT lung screening performed on the patients at the primary care clinic in question was far less than that of other primary care clinics within the health system and with similar demographics. This DNP project had strong organizational support from the hospital's Vice President (VP) of Operations, the Cardiovascular Services (CV) Administrator, and the Lung Nodule Program Coordinator at the health system's division and local level. Interprofessional collaboration was an essential prerequisite for this DNP project to realize its 
goals. Although strong organizational support had been displayed at the health system level and hospital level, obtaining buy-in from the medical providers and staff at the primary care clinic was essential. The first step of the lung screening process started with an accurate assessment of each patient's smoking history; this assessment was be completed by the medical assistants (MA) or the primary care providers. A strength, weaknesses, opportunities, and threats (SWOT) analysis suggested that vacancies and staff turnover within the primary care clinic undoubtedly presented a barrier towards hard-wiring the process into daily routines (seen in Appendix A). Reinforcement of the project's mission by the office manager, primary investigator (PI), care coordinators, and medical providers were essential to ensure that the project started and ended effectively.

The system-level change that will sustain this project begins with a clearly defined process for identifying eligible patients for LDCT lung screening. A process for ongoing audit and feedback was implemented so that all essential components of lung screening eligibility are addressed and documented.

\section{Implementation Plan with Timeline and Budget}

\section{Establishing a sense of urgency}

Kotter's eight-stage change process was used to facilitate this DNP project. Kotter's change process is a widely adopted change theory with proven success across various industries and organizations (Pollack \& Pollack, 2015). Kotter's change process starts by establishing a sense of urgency (Pollack \& Pollack, 2015). In the early months of 2021, the health system's VP of operations (VPO) informed the administrative director of cardiovascular services (CVS) that imaging centers in similar-sized areas performed much more LDCT scans than at the respective 
health system. The data shared by the VPO strongly suggested that more efforts were required to ensure those eligible for lung cancer screening were receiving this life-saving diagnostic. The administrative director of CVS was challenged to increase lung cancer screening performed at the health system's imaging center.

\section{Creating the guiding coalition and develop a vision and strategy}

The second and third stages of Kotter's process are forming a coalition with power to effect change and develop a vision and strategy (Pollack \& Pollack, 2015). A strong alliance for this project was created during the planning phase of this project. This coalition was championed by the VPO and the administrative director of CVS. In the months leading to this project, numerous meetings attended by key stakeholders reviewed lung screening rates and discussed strategies for improvement. One of the essential strategies identified at these meetings was this

DNP project to improve physician documentation for lung cancer screening.

\section{Communicating the change vision}

Kotter's fourth stage is to communicate the change vision (Pollack \& Pollack, 2015).

During the first week of the project's intervention, a succinct PowerPoint outlining the efficacy of LDCT lung screening and the shared decision-making process was presented to the primary care providers and office staff (see Appendix B). The PowerPoint emphasized LDCT lung screening eligibility criteria, risks, benefits, alternatives, and the evidence supporting this only screening method for improving lung cancer survival (Pyenson \& Tomicki, 2018). Kotter emphasizes the multiple efforts for communicating the vision of change should be utilized (Pollack \& Pollack, 2015). In addition to the informative PowerPoint, the clinic's care coordinator and manager reviewed the LDCT screening criteria and associated documentation 
with the medical assistants (MAs) so that they too could reinforce the change vision. A sequential overview of the project's interventions, listing the responsible individuals, can be found in Appendix C. Brochures for patients to become more informed about lung cancer screening were placed in the clinic's patient lobby (seen in Appendix D).

\section{Empowering broad-based change and generating short-term wins}

Empowering broad-based change and creating short-term wins is the next stage of Kotter's change process (Pollack \& Pollack, 2015). Since the clinic's EHR does not have the capability of automated prompts for lung cancer screening, utilizing a checklist to determine if patients are eligible for screening had the potential to improve physician compliance. An audit and feedback lung cancer screening tool was created by the project manager (seen in Appendix E) to serve as a checklist for physicians of the critical components for determining eligibility for lung cancer screening. Audits and feedback of the lung cancer screening audit tool empowered providers and office staff with up-to-date information regarding the project's status and key performance measurements.

Recognizing short-term wins were achieved through celebrating each lung screen order and increased compliance with the associated documentation. Feedback was communicated through project updates on the clinic's communication boards and via emails to the office manager and medical providers. Staff was praised for each LDCT lung screening that was ordered during the project.

\section{Consolidating gains, producing more change, anchoring new approaches}

The final stages of Kotter's change process are to consolidate gains, produce more change, and anchor new approaches (Pollack \& Pollack, 2015). Kotter's change process 
recognizes that sustainable change takes time for anchoring (Pollack \& Pollack, 2015). Until the audit and feedback process are an automated feature of the clinic's EHR, ongoing audit and feedback will be essential for consolidating gains. After the project was completed, the manager of care coordination and office managers for the primary care clinic were tasked with continuing audit and feedback of LDCT lung screening efforts.

\section{Budget considerations}

This EBP practice change project did not require any additional full-time-equivalents (FTEs) or overtime. The manager of care coordination was previously conducting chart audits for performance and outcome metrics and planned to incorporate lung cancer screening audits into the ongoing and routine workflow. The only additional expense for this project was the cost of paper and toner needed to print the lung cancer screening audit tool.

\section{Evaluation Plan}

\section{Establishing a baseline}

Baseline data for the total number of LDCT lung screens ordered and completed was retrospective and covered a four-week period before implementing the audit and feedback intervention. Data for completed LDCT orders and completed scans was obtained from the manager of the health system's imaging center. There was no baseline data for provider compliance for LDCT lung screening documentation on the audit tools, since no data existed prior to this project.

\section{Potential risks to participants and inclusion criteria}

Lung cancer screening is not without risks and includes radiation exposure, unnecessary invasive procedures, false-positive results, and emotional distress (Center for Disease Control 
and Prevention, 2020). However, efforts taken to minimize risks included offering lung cancer screening only to those who met recommended guidelines. In addition, the primary care provider conducted a shared decision-making session to explain risks, benefits, and alternatives with respective patients before ordering lung cancer screening (Moyer, 2014).

The audit inclusion criteria was for patients between the ages of 55 and 80 years that were current smokers or had a history of smoking; this age group was selected based on the USPSTF recommendations for lung cancer screening (Moyer, 2014). Inclusion criteria for LDCT lung screen orders was for patients that met all of the following criteria: the patient was between the age of 55 and 80 years, a current smoker or one who quit smoking within the past 15 years, had no symptoms of lung cancer, had at least a 30 pack-year smoking history, and was willing to undergo treatment for lung cancer (McDonnell et al., 2019).

\section{Data collection}

The data for this project was collected by the project manager. Data was retrieved from the lung cancer screening audit tool. Weekly updates from the health system's imaging center was provided regarding the number of LDCT lung screens ordered. Data during the preimplementation period and throughout the project's lifespan was collected on a weekly basis and entered into the data collection tool (seen in Appendix F). Face validity of the lung cancer screening audit tool and the data collection tool was determined after it was reviewed by the lung nodule program's administrative director.

\section{Data storage}

The data collected did not contain any patient identifiers and was stored within the project manager's personal computer and the project manager's cloud drive. The project manager's 
personal computer was protected with password and facial recognition technology. No data that may have revealed the identity of the participants was used. No information that may readily identify participants was recorded within any of the data collection tools used for this audit and feedback project.

\section{Evaluation design and evaluation tools}

The evaluation of outcomes for this project was achieved through a pre and post-design. Data used included descriptive and nominal statistics of the participant population and medical providers. Outcome, process, balancing, and sustainability measures are depicted in Appendix G. Data analysis was performed using the Intellectus software. The chi-squared test was used to test the effectiveness of the intervention on the identified outcomes. Since lung cancer screening can reduce lung cancer deaths by 20 percent, clinical significance was be determined by a significant increase in LDCT lung cancer screening from the baseline data (Velez Martinez et. al. 2020). A timeline of the project's schedule is shown in Appendix H.

\section{Results}

\section{Data collection tools and data collection process}

Baseline data was collected by the PM for the four weeks prior to the intervention phase of the project. The clinic's manager of care coordination provided a weekly report that contained the number of patients treated each week, including the patient's age and sex; this demographic information, without any patient identifiers, was recorded in the data collection tool (see Appendix F) during all phases of the project. The weekly demographic and patient volume reports were generated directly from the clinic's EHR. The weekly demographic reports were stored on one of the clinic's computers and were password protected. During the intervention and 
evaluation phase of the project, the Lung Cancer Screening Audit Tool (LCSAT) was completed by the medical assistants assigned to each medical provider (see Appendix E). The completed information was shared with the medical provider to determine if each patient met LDCT lung cancer screening eligibility. The LCSATs contained no patient identifiers and were stored by the PM in a file drawer contained within one of the clinic's offices. Participant inclusion criteria for the LCSAT were patients ages 55 to 80 years and who were active or former smokers; this inclusion criterion was per the USPSTF guidelines (Moyer, 2014). All information from the LCSATs was also entered in the data collection tool by the PM. The PM created all data collection tools, and the face value for each tool was verified by the health system's Administrative Director of Cardiovascular Services.

\section{Evaluation design}

The project used a pre and post-evaluation design for outcome, process, balancing, and sustainability measurements (see Appendix G). The primary outcome measure was an observed increase in the number of LDCT lung cancer screens from the baseline to intervention and evaluation phases of the project. The data collected and analyzed included nominal and interval data. All data analysis was completed through the Intellectus software.

\section{Analysis of the evaluation data}

Descriptive statistics were obtained, and the Chi-square test was used to analyze the data. The project intervention phase $(n=1383,36.4 \%)$, contained the largest number of patients seen at the clinic, followed by the baseline phase $(n=1218,32 \%)$, and lastly the evaluation phase $(\mathrm{n}=1197,31.5 \%)$ (see Appendix I, Table 1). The most frequently observed category for LDCT Audit Forms submitted for evaluation per patient was ( $\mathrm{n}=3545,93.3 \%$ ), 
followed by patients that did not have an LDCT Audit Form submitted $(\mathrm{n}=253,6.7 \%)$ (see Appendix I, Table 1). The most frequently observed category for LDCT orders during the project was No $(n=3779,99.5 \%)$, meaning that an LDCT was not ordered, followed by Yes $(n=19$, 0.5\%), meaning that an LDCT was ordered (see Appendix I, Table 1). The most frequent observation regarding the determination of whether the patients met LDCT lung screen eligibility per the LDCT Audit Forms was No $(\mathrm{n}=235,84.2 \%)$, followed by Yes $(\mathrm{n}=35,12.5 \%)$, and Unable to determine $(n=9,3.2 \%)$ (see Appendix I, Table 2). The rate of completion of the LDCT eligibility criteria questions on the submitted LDCT Audit Forms was Yes $(n=251$, $89.96 \%)$ compared to No $(n=28,10.04 \%)$ of the submitted LDCT Audit Forms that were not completely filled out (see Appendix I, Table 3). A "No" answer to any of the questions on the LDCT Audit Form would make the patient ineligible for LDCT lung cancer screening. The most frequent reason that a patient was ruled out for LDCT lung cancer screening, per the LDCT Audit Forms, was because the patient quit smoking more than 15 years ago $(n=146,52.33 \%)$, followed by patients having a pack-year history less than $30(\mathrm{n}=116,41.58 \%)$ (see Appendix I, Table 4 for a complete listing of reasons the patients were ineligible for LDCT lung cancer screening). The intervention phase of the project had nearly double the number of LDCT orders compared to the baseline (baseline $n=5$, intervention $n=9$ ). Determination of whether the number of LDCT orders was dependent on the project phase was established by a Chi-square test. The Chi-square test did not show a statistically significant relationship $(\mathrm{p}=0.609)$, based on an alpha value of 0.05 , between the project intervention phase and the number of LDCT orders (see Appendix I, Table 5). 


\section{Determination of a clinical significance}

The National Lung Screening Trial (NLST) showed that LDCT lung cancer screening could reduce mortality rates among high-risk patients by $20 \%$ (Honey, 2020). The number of patients needed to screen to produce clinically significant findings is 320 (Moyer, 2014). Although just $18.6 \%$ of patients diagnosed with lung cancer have a five-year survival rate, $88 \%$ of patients diagnosed with lung cancer in its earliest stage live ten years after the lung cancer diagnosis (Pyenson \& Tomicki, 2018). The completed LDCT lung cancer screening scans during this project showed that most of the patients scanned $(n=8,42.1 \%)$ had negative findings (see Appendix I, Table 6). However, three of the scans yielded positive results, with nodules ranging from two to five millimeters (see Appendix I, Table 6). The patients with positive findings will be followed by the health system's lung nodule coordinator for further evaluation and treatment to optimize the chances of survival.

\section{Impact}

\section{Effect on practice problem and practice}

The practice problem for this DNP project pertained to increasing LDCT lung screening at a primary care clinic through an audit and feedback intervention. Although the results of the project were not statistically significant, the number of LDCT lung screenings nearly doubled during the intervention phase of the project $(n=9)$ in comparison to the baseline phase $(n=5)$. However, during the evaluation phase, the number of LDCT lung screenings was that of the baseline quantity. The use of the Lung Cancer Screening Audit Tool (LCSAT), which was introduced to practice during the intervention phase of the project, allowed the providers to gain 
knowledge of all criteria necessary to determine whether patients met LDCT lung screening eligibility. Prior to using the LCSAT, the clinic's providers had no way of knowing whether patients met eligibility criteria until after the LDCT lung screen was ordered. This lack of clarity within the EHR may have contributed to fewer LDCT lung screen orders.

\section{Future implications and recommendations for sustainability}

To prevent duplication of work, future modifications to the EHR that includes LDCT lung screen eligibility requirements within the social history may increase provider awareness and LDCT lung screen orders. Until the EHR can be modified appropriately, continued use of the LCSAT will ensue. For the sustainability of this project, the Manager of Care Coordination expanded the use of the LCSAT within all of the health system's clinics and has tasked each clinic's manager with ongoing audit and feedback.

\section{Barriers and limitations}

The most significant limitation of the audit and feedback intervention was that it bifurcated and duplicated the provider's workflow. In addition to documenting each patient's smoking status within the EHR, the providers were expected to document the same information on the LCSATs. This duplication of work negatively affected staff buy-in and compliance.

As this DNP project unfolded, it became apparent that the site of the project had numerous competing priorities. The project took place during the peak of the COVID 19 pandemic for its locals. The leaders and providers at the clinic were undoubtedly concerned with how the pandemic would impact operations and the care of their population. In addition, the clinic was experiencing a challenging level of turnover among its frontline clinical staff. 
Another significant limitation was that the audit process required manual audits of data from the LCSATs. Manual audits can be a barrier to sustainability since it is costly and timeconsuming. Furthermore, with manual audits, there is no way of determining if the information gleaned from the LCSATs is congruent with the data entered into the EHR. Incorporating the entire process into the EHR would streamline the workflow and provide opportunities for electronic audits in the future.

\section{Dissemination Plan}

An essential component of DNP practice is evaluating nursing practice, reviewing best practice within the literature, and disseminating the best evidence into practice (American Association of Colleges of Nursing, 2006). At the close of the project, a PowerPoint presentation was presented by the PM and the Administrative Director of Cardiovascular Services at the hospital's Lung Nodule Program Meeting. The PowerPoint presentation detailed the collected data, identified barriers to success, future recommendations, and an opportunity for questions and interprofessional discussion. In attendance at the Lung Nodule Program Meeting, was the vice president (VP) of operations, the lung nodule coordinator, pulmonologists, oncologists, lung cancer navigators, and the director of imaging services. A PowerPoint presentation will also be provided to the respective clinic's medical providers and office staff. The PowerPoint presentation will highlight data collected within the project, demographic measurements, process measurements, outcome measurements, limitations, lessons learned, and future recommendations.

Dissemination for this project at the regional level includes plans for presenting the project's findings through a poster presentation at the Florida Organization of Nurse 
Executives'(FONE) annual conference. National dissemination for this project will include plans to submit this project's manuscript to the Online Journal of Nursing Issues (OJIN) for publication. The OJIN journal was selected for national dissemination because it a subsidiary of the American Nurses Association and is widely accessible through its online format (American Nurses Associatin, n.d.). Lastly, the project's final manuscript will be submitted to the Scholarship and Open Access Repository (SOAR) at the University of St. Augustine. The SOAR website's academic collection includes student's research work, dissertations, DNP projects, and capstone projects (University of St. Augustine, n.d.).

\section{Conclusion}

Lung cancer has a devastating impact on individuals and family, worldwide (Velez Martinez et al., 2020). Lung cancer screening can lower lung cancer mortality rates by $20 \%$ (Velez Martinez et al., 2020). LDCT lung cancer screening is the only approved method for detecting lung cancer in its early stages (CDC, 2020). Unfortunately, new lung cancer cases in Florida increase by 58 per 100,000 individuals annually (American Lung Association, 2020). Duval County, Florida, experienced the highest number of lung cancer cases throughout the 1990s and is currently among the Florida counties with the highest number of new lung cancer cases (Tousey et al., 1999; Florida Department of Health, 2019).

The intent of this DNP project was to increase the number of lung cancer screenings within a primary care clinic in Duval County, Florida. Studies show that audit and feedback is an evidence-based strategies for increasing preventative screening (Hwang et al., 2019; Murphy et al.,2017). Although this DNP project was able to increase lung cancer screening through the use 
of audits and feedback, the results were not statistically significant. Until the lung cancer screening eligibility determination process is hard-wired within the EHR, sustainability for this project will be achieved through ongoing audit and feedback. 
References

American Cancer Society. (2021a, January 9). Lung cancer survival rates.

https://www.cancer.org/cancer/lung-cancer/detection-diagnosisstaging/survivalrates.html

American Cancer Society. (2021b, January 12). Lung cancer statistics. https://www.cancer.org/cancer/lung-cancer/about/key-statistics.html

American College of Chest Physicians. (2020, July 31). World Lung Cancer Day 2020 Fact

Sheet. American College of Chest Physicians. https://www.chestnet.org/News/CHESTNews/2020/07/World-Lung-Cancer-Day-2020-Fact-Sheet

American Lung Association. (2020). Lung cancer state data: Florida. /research/state-oflungcancer/states/florida

American Nurses Association. (n.d.). About OJIN. Retrieved from http://ojin.nursingworld.org/MainMenuCategories/ANAMarketplace/ANAPeriodicals/OJ IN/FunctionalMenu/AboutOJIN

Baxter, N. N., Sutradhar, R., Li, Q., Daly, C., Honein-AbouHaidar, G. N., Richardson, D. P., Del Giudice, L., Tinmouth, J., Paszat, L., \& Rabeneck, L. (2017). Do primary care provider strategies improve patient participation in colorectal cancer screening? The American Journal of Gastroenterology, 112(4), 622-632. https://doi.org/10.1038/ajg.2017.4

CDX Technologies. (n.d.). Demographics by Zip Code. Retrieved from https://www.cdxtech.com/tools/demographicdata/

Center for Disease Control and Prevention. (2020, September 23). Who should be screened for lung cancer? https://www.cdc.gov/cancer/lung/basic_info/screening.htm 
Dang, D., \& Dearholt, S. (2017). John Hopkins nursing evidence-based practice: Model and guidelines (3rd ed.). Sigma Theta Tau International.

Dang, Deborah, \& Dearholt, S. (2018). John Hopkins nursing evidence-based practice (Third [ebook]). Sigma Theta Tau International.

Feldman, J., Davie, S., \& Kiran, T. (2017). Measuring and improving cervical, breast, and colorectal cancer screening rates in a multi-site urban practice in Toronto, Canada. BMJ Open Quality, 6(1), u213991.w5531. https://doi.org/10.1136/bmjquality.u213991.w5531

Florida Department of Health. (n.d.). Lung cancer deaths in Duval County. Retrieved from http://www.flhealthcharts.com/ChartsReports/rdPage.aspx?rdReport=ChartsMaps.charts Mapper\&rdRequestForwarding=Form

Florida Department of Health. (2019). Lung cancer deaths in Florida. http://www.flhealthcharts.com/charts/DataViewer/DeathViewer/DeathViewer.aspx ?indN umber $=0092$

Hazell, S. Z., Fu, W., Hu, C., Voong, K. R., Lee, B., Peterson, V., Feliciano, J. L., Nicholas, L. H., McNutt, T. R., Han, P., \& Hales, R. K. (2020). Financial toxicity in lung cancer: An assessment of magnitude, perception, and impact on quality of life. Annals of Oncology, 31(1), 96-102. https://doi.org/10.1016/j.annonc.2019.10.006

Honey, K. (2020, March 23). Screening reduces lung cancer mortality but is underutilized. American Association for Cancer Research (AACR). https://www.aacr.org/professionals/blog/screening-reduces-lung-cancer-mortality-butisunderutilized/

Hughes-Carter, D., \& Hoebeke, R. (2016). Screening for diabetic kidney disease in primary care for the underinsured: A quality improvement initiative-ScienceDirect. Applied Nursing 
Research, 30, 148-153. https://doi.org/dx.doi.org/10.1016/j.apnr.2015.11.008

Huo, J., Hong, Y.-R., Bian, J., Guo, Y., Wilkie, D. J., \& Mainous, A. G. (2019). Low rates of patient-reported physician-patient discussion about lung cancer screening among current smokers: Data from health information national trends survey. Cancer Epidemiology and Prevention Biomarkers, 28(5), 963-973. https://doi.org/10.1158/1055-9965.EPI-18-0629

Hwang, A. S., Harding, A. S., Chang, Y., O’Keefe, S. M., Horn, D. M., \& Clark, A. L. (2019). An audit and feedback intervention to improve internal medicine residents' performance on ambulatory quality measures: A randomized controlled trial. Population Health Management, 22(6), 529-535. https://doi.org/10.1089/pop.2018.0217

Ivers, N. (2012). Audit and feedback: Effects on professional practice and healthcare outcomes. Cochrane Database of Systematic Reviews, 7. http://prxusa.lirn.net/login?url=http://search.ebscohost.com/login.aspx?direct=true\&db=e dschh\&A $\mathrm{N}=$ edschh. $\mathrm{CD} 000259 \&$ site $=$ eds-live

Ivers, N. M., Sales, A., Colquhoun, H., Michie, S., Foy, R., Francis, J. J., \& Grimshaw, J. M. (2014). No more 'business as usual' with audit and feedback interventions: Towards an agenda for a reinvigorated intervention. Implementation Science, 9(1), 14. https://doi.org/10.1186/1748-5908-9-14

Jeon, S. M., Kwon, J.-W., Choi, S. H., \& Park, H.-Y. (2019). Economic burden of lung cancer: A retrospective cohort study in South Korea, 2002-2015. PLoS ONE, 14(2). https://doi.org/10.1371/journal.pone.0212878 
Jonah, L., Pefoyo, A. K., Lee, A., Hader, J., Strasberg, S., Kupets, R., Chiarelli, A. M., \& Tinmouth, J. (2017). Evaluation of the effect of an audit and feedback reporting tool on screening participation: The Primary Care Screening Activity Report (PCSAR). Preventive Medicine, 96, 135-143. https://doi.org/10.1016/j.ypmed.2016.12.002

Kassem, K., \& Laird, C. (2019). Developing a successful LDCT program in a comprehensive community cancer center. Oncology Issues, 34(1), 60-67. https://doi.org/10.1080/10463356.2018.1553421

McDonnell, K. K., Estrada, R. D., Dievendorf, A. C., Blew, L., Sercy, E., Khan, S., Hardin, J. W., Warden, D., \& Eberth, J. M. (2019). Lung cancer screening: Practice guidelines and insurance coverage are not enough. Journal of the American Association of Nurse Practitioners, 31(1), 33-45. https://doi.org/10.1097/JXX.0000000000000096

Mohiuddin, S., \& Mohteshamuddin, K. (2020). Combination model for sustainable change by utilizing the Kotters change model and the Hersey \& Blanchards leadership model for improving medication errors reporting. Journal of Medical and Allied Sciences, 10(1), 25-32. https://doi.org/10.5455/jmas.76372

Moyer, V. A. (2014). Screening for lung cancer: U.S. preventive services task force recommendation statement. Annals of Internal Medicine, 160(5), 330-338. https://doi.org/10.7326/M13-2771

Pham, D., Bhandari, S., Pinkston, C., Oechsli, M., \& Kloecker, G. (2020). Lung cancer screening registry reveals low-dose CT screening remains heavily underutilized. Clinical Lung Cancer, 21(3), e206-e211. https://doi.org/10.1016/j.cllc.2019.09.002 Pollack, J., \& Pollack, R. (2015). Using Kotter's eight stage process to manage an organisational change program: Presentation and practice. Systemic Practice \& Action Research, 28(1), 
51-66. https://doi.org/10.1007/s11213-014-9317-0

Powell, B. J., Waltz, T. J., Chinman, M. J., Damschroder, L. J., Smith, J. L., Matthieu, M. M., Proctor, E. K., \& Kirchner, J. E. (2015). A refined compilation of implementation strategies: Results from the Expert Recommendations for Implementing Change (ERIC) project. Implementation Science, 10. https://doi.org/10.1186/s13012-015-0209-1

Proctor, E., Silmere, H., Raghavan, R., Hovmand, P., Aarons, G., Bunger, A., Griffey, R., \& Hensley, M. (2011). Outcomes for implementation research: Conceptual distinctions, measurement challenges, and research agenda. Administration and Policy in Mental Health and Mental Health Services Research, 38(2), 65.

Riva, J. J., Malik, K. M. P., Burnie, S. J., Endicott, A. R., \& Busse, J. W. (2012). What is your research question? An introduction to the PICOT format for clinicians. Journal of the Canadian Chiropractic Association, 56(3), 167-171.

Sheehan, D. F., Criss, S. D., Chen, Y., Eckel, A., Palazzo, L., Tramontano, A. C., Hur, C., Cipriano, L. E., \& Kong, C. Y. (2019). Lung cancer costs by treatment strategy and phase of care among patients enrolled in Medicare. Cancer Medicine, 1, 94. https://doi.org/10.1002/cam4.1896

Singh, A., Danda, V., Van Swol, L., Scott, J. P., Brandow, A. M., \& Panepinto, J. A. (2021). Recommendation to reality: Closing the transcranial Doppler screening gap for children with sickle cell anemia. Pediatric Blood \& Cancer, 68(2), e28831. https://doi.org/10.1002/pbc.28831

Stock, D., Rabeneck, L., Baxter, N. N., Paszat, L. F., Sutradhar, R., Yun, L., \& Tinmouth, J. (2017). A centrally generated primary care physician audit report does not improve colonoscopy uptake after a positive result on a fecal occult blood test in Ontario's 
ColonCancerCheck program. Current Oncology (Toronto, Ont.), 24(1), 47-51. https://doi.org/10.3747/co.24.3025

Toumazis, I., Bastani, M., Han, S. S., \& Plevritis, S. K. (2020). Risk-Based lung cancer screening: A systematic review. Lung Cancer, 147, 154-186. https://doi.org/10.1016/j.lungcan.2020.07.007

Tousey, P. M., Wolfe, K. W., Mozeleski, A., Mohr, D. L., Cantrell, B. B., O’Donnell, M., Heath, C. W., \& Blot, W. J. (1999). Determinants of the excessive rates of lung cancer in northeast Florida. Southern Medical Journal, 92(5), 493-501. https://doi.org/10.1097/00007611-199905000-00009

University of St. Augustine. (n.d.). Student Research. Retrieved from https://soar.usa.edu/studentresearch/

US Preventative Services Task Force. (2021, March 9). Final recommendation statement: Lung cancer screening. US Preventative Services Task Force. https://www.uspreventativeservicestaskforce.org/supstf/recommendation/lungcancerscreening

Velez Martinez, C., Thurlapati, A., Hirani, S., Larea Cole, C., Abad, J., \& Beedupalli, K. (2020). Assessing risk-based LDCT screening strategies versus the current USPSTF lung cancer screening recommendations at an institutional setting. Journal of Clinical Oncology, 38(15). https://doi.org/10.1200/JCO.2020.38.15 
Table 1

Summary of Primary Research Evidence

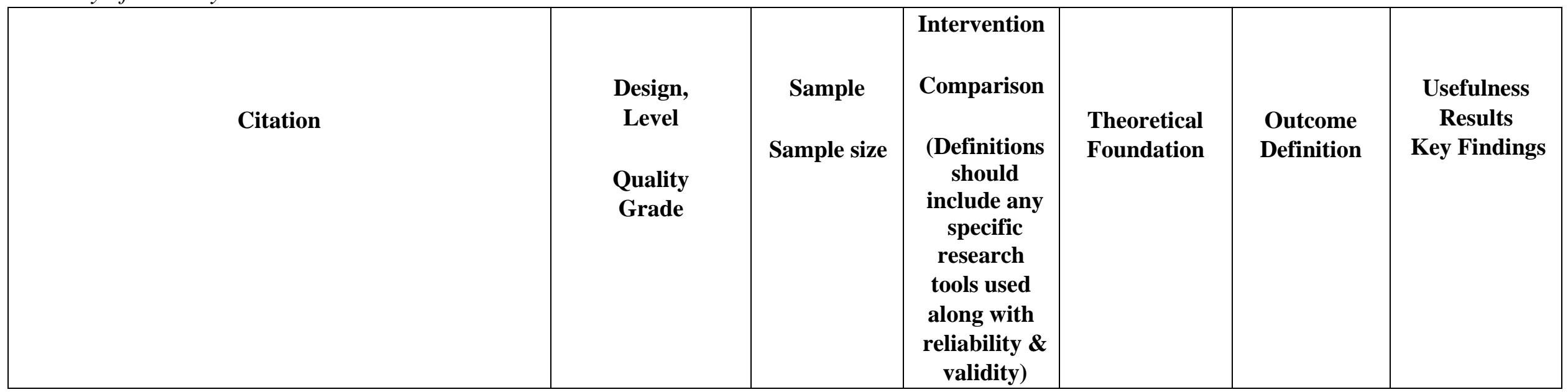




\begin{tabular}{|c|c|c|c|c|c|c|}
\hline $\begin{array}{l}\text { Baxter, N. N., Sutradhar, R., Li, Q., Daly, C., } \\
\text { HoneinAbouHaidar, G. N., Richardson, D. P., Del } \\
\text { Giudice, L., Tinmouth, J., Paszat, L., \& Rabeneck, } \\
\text { L. (2017). Do primary care provider strategies } \\
\text { improve patient participation in colorectal cancer } \\
\text { screening? The American Journal of } \\
\text { Gastroenterology, 112(4), 622-632. } \\
\text { https://doi.org/10.1038/ajg.2017.4 }\end{array}$ & $\begin{array}{l}\text { Design: } \\
\text { Quasiexperimental, } \\
\text { randomized survey } \\
\text { Level: II Grade: B. } \\
\text { Good }\end{array}$ & $\begin{array}{l}\text { Sample: } \\
\text { Primary care } \\
\text { physicians } \\
\text { (PCPs) in } \\
\text { Ontario } \\
\text { (family } \\
\text { physicians, } \\
\text { general } \\
\text { practitioners) } \\
\text { and patients } \\
\text { eligible for } \\
\text { colorectal } \\
\text { cancer } \\
\text { screening. } \\
\text { Sample Size: } \\
\text { 147,834 } \\
\text { patients and } \\
717 \text { PCPs }\end{array}$ & $\begin{array}{l}\text { Intervention: } \\
\text { Standard } \\
\text { approach } \\
\text { prompts PCP } \\
\text { of need for } \\
\text { screening on } \\
\text { eligible } \\
\text { patients or a } \\
\text { systematic } \\
\text { process that } \\
\text { generates } \\
\text { lists of } \\
\text { patients that } \\
\text { need } \\
\text { colorectal } \\
\text { screening } \\
\text { Comparison: } \\
\text { No } \\
\text { systematic } \\
\text { practicebased } \\
\text { strategy }\end{array}$ & $\begin{array}{l}\text { Theoretical } \\
\text { foundation: No } \\
\text { conceptual or } \\
\text { theoretical } \\
\text { framework was } \\
\text { mentioned }\end{array}$ & $\begin{array}{l}\text { Outcomes: A } \\
\text { modified } \\
\text { Dillman-style } \\
\text { multimodal } \\
\text { approach was } \\
\text { utilized for the } \\
\text { survey. The } \\
\text { primary } \\
\text { outcome was } \\
\text { up-to-date } \\
\text { colorectal } \\
\text { screening for } \\
\text { the 2-year } \\
\text { interval }\end{array}$ & $\begin{array}{l}\text { Multivariate } \\
\text { analysis was } \\
\text { used to } \\
\text { determine the } \\
\text { effectiveness of } \\
\text { multiple } \\
\text { strategies for } \\
\text { improving the } \\
\text { timeliness of } \\
\text { colorectal } \\
\text { screening. The } \\
\text { only } \\
\text { statistically } \\
\text { effective } \\
\text { method for } \\
\text { preventing } \\
\text { overdue } \\
\text { colorectal } \\
\text { screening was a } \\
\text { systematic } \\
\text { process for } \\
\text { generating lists } \\
\text { for the }\end{array}$ \\
\hline & & & & & & $\begin{array}{l}\text { providers }(95 \% \\
\text { CI } 1.02-1.16 . P \\
=0.03)\end{array}$ \\
\hline
\end{tabular}




\begin{tabular}{|c|c|c|c|c|c|c|}
\hline $\begin{array}{l}\text { Feldman, J., Davie, S., \& Kiran, T. (2017). Measuring } \\
\text { and improving cervical, breast, and colorectal cancer } \\
\text { screening rates in a multi-site urban practice in } \\
\text { Toronto, Canada. BMJ Open Quality, 6(1), } \\
\text { u213991.w5531. } \\
\text { https://doi.org/10.1136/bmjquality.u213991.w5531 }\end{array}$ & $\begin{array}{l}\text { Design: } \\
\text { Quasiexperimental, } \\
\text { Quality } \\
\text { Improvement } \\
\text { Project } \\
\text { Level: III Grade: } \\
\text { C. } \\
\text { Low quality }\end{array}$ & $\begin{array}{l}\text { Sample: } \\
\text { Primary care } \\
\text { physicians and } \\
\text { their patients } \\
\text { who qualified } \\
\text { for cervical, } \\
\text { breast, and } \\
\text { colorectal } \\
\text { screening } \\
\text { Sample size: } \\
\text { one physician } \\
\text { practice in } \\
\text { Ontario }\end{array}$ & $\begin{array}{l}\text { Intervention: } \\
\text { Physicians } \\
\text { within the } \\
\text { respective } \\
\text { practice } \\
\text { were given } \\
\text { audit and } \\
\text { feedback, } \\
\text { according to } \\
\text { Ontario's } \\
\text { cancer } \\
\text { screening } \\
\text { guidelines } \\
\text { and the } \\
\text { cancer } \\
\text { screening } \\
\text { registry. No } \\
\text { control } \\
\text { group was } \\
\text { used but } \\
\text { a pre and } \\
\text { post method } \\
\text { was } \\
\text { used to } \\
\text { compare } \\
\text { results }\end{array}$ & $\begin{array}{l}\text { Theoretical } \\
\text { foundation: } \\
\text { No } \\
\text { conceptual or } \\
\text { theoretical } \\
\text { framework } \\
\text { was } \\
\text { mentioned }\end{array}$ & $\begin{array}{l}\text { Outcomes: } \\
\text { Percentage of } \\
\text { patients up- } \\
\text { todate with } \\
\text { cervical, } \\
\text { breast, and } \\
\text { colorectal } \\
\text { cancer } \\
\text { screening }\end{array}$ & $\begin{array}{l}\text { Cervical cancer } \\
\text { screenings } \\
\text { increased by } \\
5 \%(\mathrm{p}<0.05) \text {, } \\
\text { breast cancer } \\
\text { screening } \\
\text { increased by } \\
9 \%(\mathrm{p}<0.05) \text {, } \\
\text { and colorectal } \\
\text { screening } \\
\text { increased by } \\
6 \% \text { (p<0.05). } \\
\text { Limitations } \\
\text { include a single } \\
\text { practice site } \\
\text { and small } \\
\text { sample size } \\
\text { that may not } \\
\text { provide } \\
\text { generalizable } \\
\text { results. }\end{array}$ \\
\hline $\begin{array}{l}\text { Hughes-Carter, D., \& Hoebeke, R. (2016). Screening for } \\
\text { diabetic kidney disease in primary care for the } \\
\text { underinsured: A quality improvement initiative. } \\
\text { Applied Nursing Research, 30, 148-153. } \\
\text { https://doi.org/dx.doi.org/10.1016/j.apnr.2015.11.008 }\end{array}$ & $\begin{array}{l}\text { Design: } \\
\text { Quasiexperimental, } \\
\text { quality } \\
\text { improvement study } \\
\text { Level: III Grade: } \\
\text { B. } \\
\text { Good }\end{array}$ & $\begin{array}{l}\text { Sample: } \\
\text { Patients at } \\
\text { Two } \\
\text { Midwest } \\
\text { primary care } \\
\text { clinics } \\
\text { Sample Size: } \\
\text { Preintervention } \\
\text { patient sample } \\
\text { (n=453), } \\
\text { postintervention }\end{array}$ & $\begin{array}{l}\text { Intervention: } \\
\text { Audit and } \\
\text { feedback, } \\
\text { was used to } \\
\text { inform } \\
\text { providers of } \\
\text { patients } \\
\text { eligible for } \\
\text { diabetic } \\
\text { kidney } \\
\text { screening. } \\
\text { The } \\
\text { validated }\end{array}$ & $\begin{array}{l}\text { Theoretical } \\
\text { foundation: } \\
\text { No } \\
\text { conceptual } \\
\text { or } \\
\text { theoretical } \\
\text { framework } \\
\text { was } \\
\text { mentioned }\end{array}$ & $\begin{array}{l}\text { Outcome: The } \\
\text { percentage of } \\
\text { microalbumin } \\
\text { testing for } \\
\text { determining } \\
\text { diabetic } \\
\text { kidney } \\
\text { disease } \\
\text { definition: }\end{array}$ & $\begin{array}{l}\text { Post } \\
\text { intervention } \\
\text { chart audits } \\
\text { showed a } \\
\text { postintervention } \\
\text { compliance of } \\
75 \% \text {, up from } \\
\text { the } 50.3 \% \\
\text { preintervention } \\
\text { rate. This study } \\
\text { is limited } \\
\text { because of a }\end{array}$ \\
\hline
\end{tabular}




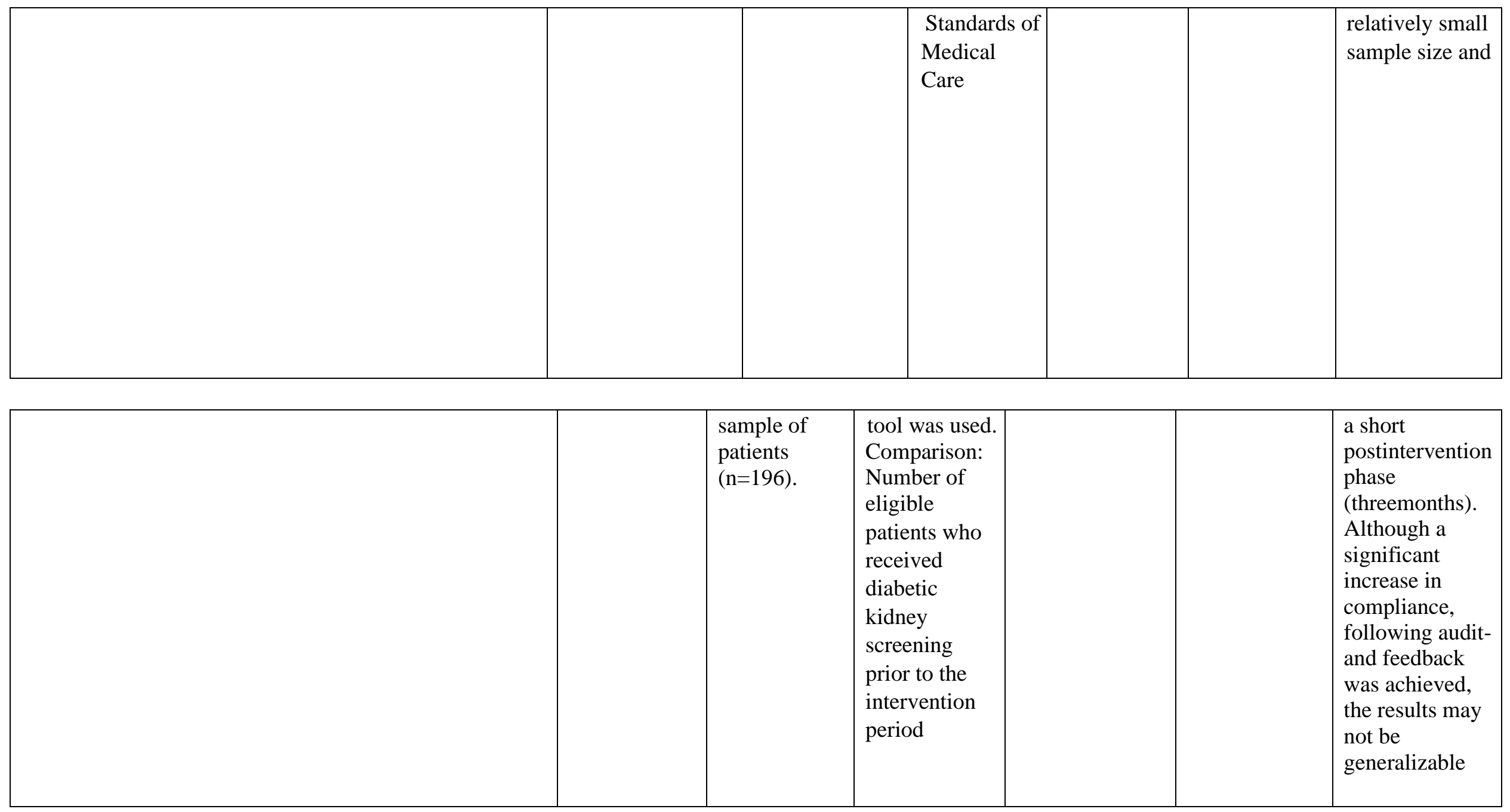




\begin{tabular}{|c|c|c|c|c|c|c|}
\hline $\begin{array}{l}\text { Hwang, A. S., Harding, A. S., Chang, Y., O'Keefe, S. } \\
\text { M., Horn, D. M., \& Clark, A. L. (2019). An audit and } \\
\text { feedback intervention to improve internal medicine } \\
\text { residents' performance on ambulatory quality } \\
\text { measures: A randomized controlled trial. Population } \\
\text { Health Management, 22(6), 529-535. } \\
\text { https://doi.org/10.1089/pop.2018.0217 }\end{array}$ & $\begin{array}{l}\text { Design: } \\
\text { Three-armed } \\
\text { randomized } \\
\text { clinical trial } \\
\text { Level: I } \\
\text { Grade: A. } \\
\text { High quality }\end{array}$ & $\begin{array}{l}\text { Sample: } 96 \\
\text { internal } \\
\text { medicine first } \\
\text { and second } \\
\text { year residents } \\
\text { and } 6363 \\
\text { patients were } \\
\text { randomized. }\end{array}$ & $\begin{array}{l}\text { Intervention: } \\
\text { Audit and } \\
\text { feedback was } \\
\text { provided to } \\
\text { primary care } \\
\text { physicians to } \\
\text { impact } \\
\text { ambulatory } \\
\text { quality } \\
\text { measures } \\
\text { (AQMs) } \\
\text { Comparison: } \\
\text { Physicians } \\
\text { that did not } \\
\text { receive audit } \\
\text { and feedback } \\
\text { for AQMs }\end{array}$ & $\begin{array}{l}\text { No conceptual } \\
\text { or theoretical } \\
\text { framework was } \\
\text { mentioned }\end{array}$ & $\begin{array}{l}\text { Outcome: The } \\
\text { outcome } \\
\text { measure was } \\
\text { colorectal } \\
\text { screening } \\
\text { rates, } \\
\text { composite } \\
\text { quality scores, } \\
\text { and cervical } \\
\text { cancer } \\
\text { screening rates }\end{array}$ & $\begin{array}{l}\text { Cervical cancer } \\
\text { screening was } \\
\text { completed } 77 \% \\
\text { for intervention } \\
\text { group and } \\
65.3 \% \\
(P<0.01) \text { for the } \\
\text { control group. } \\
\text { Colorectal } \\
\text { screening was } \\
\text { completed } \\
72.5 \% \text { for the } \\
\text { intervention } \\
\text { group and } \\
64.6 \% \text { (P<0.01) } \\
\text { for the control } \\
\text { group. The } \\
\text { composite } \\
\text { quality score } \\
\text { was } 71.7 \% \\
\text { (P<0.01) for the } \\
\text { intervention } \\
\text { group and } \\
65.4 \% \text { for the }\end{array}$ \\
\hline
\end{tabular}




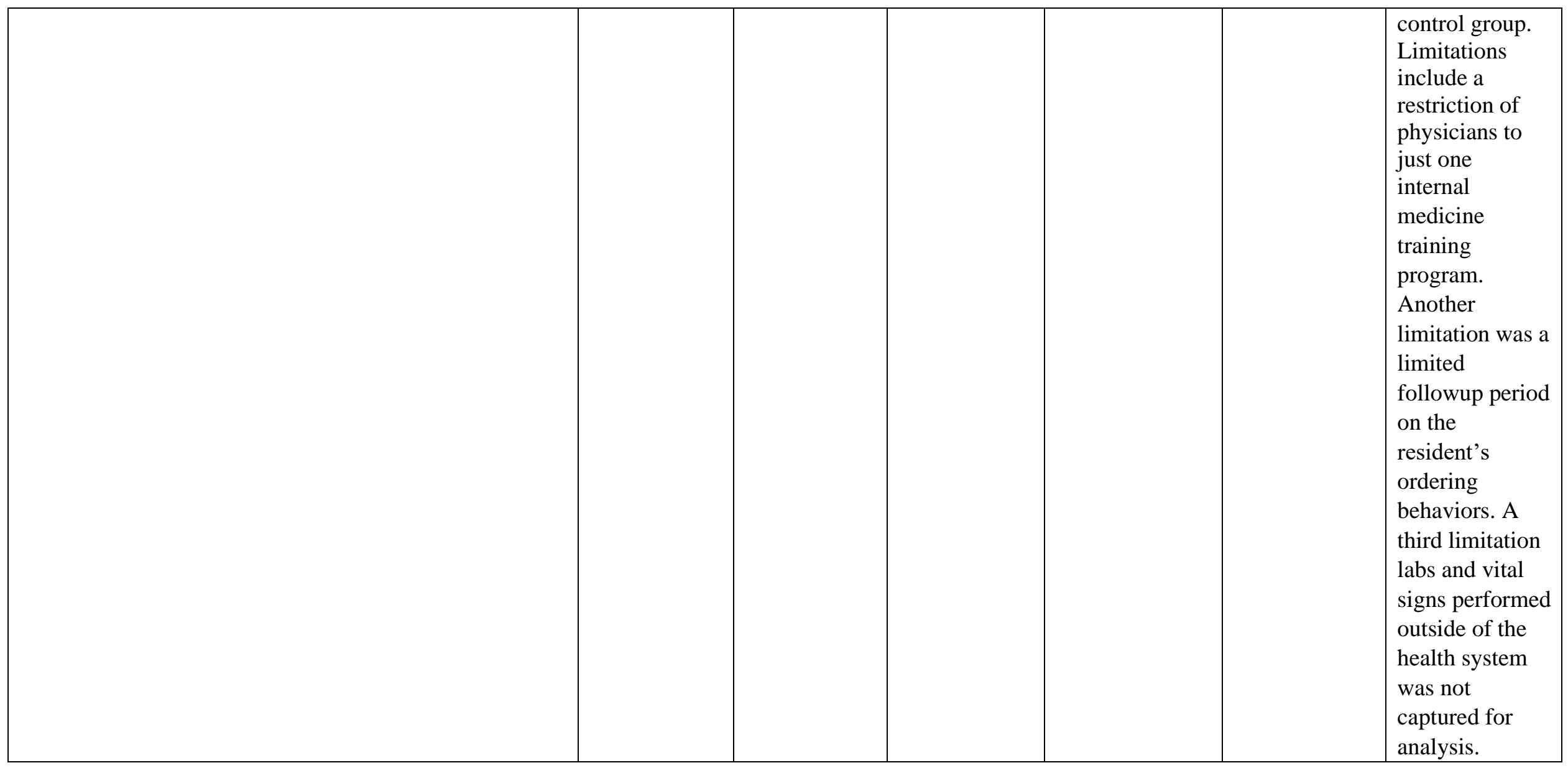




\begin{tabular}{|c|c|c|c|c|c|c|}
\hline $\begin{array}{l}\text { Jonah, L., Pefoyo, A. K., Lee, A., Hader, J., Strasberg, } \\
\text { S., Kupets, R., Chiarelli, A. M., \& Tinmouth, J. } \\
\text { (2017). Evaluation of the effect of an audit and } \\
\text { feedback reporting tool on screening participation: } \\
\text { The Primary Care Screening Activity Report } \\
\text { (PCSAR). Preventive Medicine, 96, 135-143. } \\
\text { https://doi.org/10.1016/j.ypmed.2016.12.002 }\end{array}$ & $\begin{array}{l}\text { Design: } \\
\text { Retrospective } \\
\text { cohort } \\
\text { Level: II } \\
\text { Grade: B. } \\
\text { Good }\end{array}$ & $\begin{array}{l}\text { Sample: } \\
\text { Primary care } \\
\text { physicians in } \\
\text { Ontario Size: } \\
7800 \\
\text { primary care } \\
\text { physicians }\end{array}$ & $\begin{array}{l}\text { Intervention: } \\
\text { The Primary } \\
\text { Care } \\
\text { Screening } \\
\text { Activity } \\
\text { Report } \\
\text { (PASCAR) } \\
\text { was the } \\
\text { intervention } \\
\text { used for the } \\
\text { intervention } \\
\text { group. The } \\
\text { comparison } \\
\text { group was }\end{array}$ & $\begin{array}{l}\text { Theoretical } \\
\text { foundation: } \\
\text { Elements of the } \\
\text { PASCAR are } \\
\text { found with the } \\
\text { audit and } \\
\text { feedback } \\
\text { framework } \\
\text { identified by } \\
\text { Ivers ( Ivers et } \\
\text { al., 2014) }\end{array}$ & $\begin{array}{l}\text { Outcome } \\
\text { definition: } \\
\text { The PASCAR } \\
\text { was the audit } \\
\text { and feedback } \\
\text { tool used. The } \\
\text { outcome } \\
\text { measurements } \\
\text { were the } \\
\text { number of } \\
\text { colorectal, } \\
\text { breast, and } \\
\text { cervical } \\
\text { screenings. }\end{array}$ & $\begin{array}{l}\text { The PASCAR } \\
\text { audit and } \\
\text { feedback } \\
\text { method was } \\
\text { associated with } \\
\text { marginally but } \\
\text { statistically } \\
\text { significant } \\
\text { improvements } \\
\text { in health } \\
\text { screening. }\end{array}$ \\
\hline
\end{tabular}

\begin{tabular}{|l|l|l|l|l|}
\hline & & & $\begin{array}{l}\text { patients of } \\
\text { primary care } \\
\text { physicians } \\
\text { that did not } \\
\text { use PASCAR }\end{array}$ & \\
\hline
\end{tabular}




\begin{tabular}{|c|c|c|c|c|c|c|}
\hline $\begin{array}{l}\text { Lai, X. B., Huang, Z., Chen, C. Y., \& Stephenson, M. } \\
\text { (2019). Delirium screening in patients in a palliative } \\
\text { care ward: A best practice implementation project. } \\
\text { JBI Database of Systematic Reviews and } \\
\text { Implementation Reports, 17(3), 429-441. } \\
\text { https://doi.org/10.11124/JBISRIR-2017-003646 }\end{array}$ & $\begin{array}{l}\text { Design: } \\
\text { Quasiexperimental } \\
\text { Level: III } \\
\text { Grade: Good }\end{array}$ & $\begin{array}{l}\text { Sample: } \\
\text { Staff nurses } \\
\text { in a palliative } \\
\text { care ward in } \\
\text { Shanghai } \\
\text { China } \\
\text { Sample size: } \\
18 \text { nurses }\end{array}$ & $\begin{array}{l}\text { Intervention: } \\
\text { The Joanna } \\
\text { Briggs } \\
\text { Institute's } \\
\text { Practical } \\
\text { Application } \\
\text { of Clinical } \\
\text { Evidence } \\
\text { System and } \\
\text { the Getting } \\
\text { Research into } \\
\text { Practice tool } \\
\text { were used. } \\
\text { An audit was } \\
\text { performed on } \\
\text { nursing } \\
\text { compliance } \\
\text { with delirium } \\
\text { screening. } \\
\text { Feedback } \\
\text { was given for } \\
\text { variances. } \\
\text { Comparison: } \\
\text { The } \\
\text { comparison } \\
\text { was the time } \\
\text { prior to } \\
\text { utilizing audit } \\
\text { and feedback } \\
\text { methods. }\end{array}$ & $\begin{array}{l}\text { The Joanna } \\
\text { Briggs Institute } \\
\text { Practical } \\
\text { Application of } \\
\text { Clinical } \\
\text { Evidence } \\
\text { System and the } \\
\text { Getting } \\
\text { Research into } \\
\text { Practice were } \\
\text { used as a } \\
\text { theoretical } \\
\text { framework for } \\
\text { this study }\end{array}$ & $\begin{array}{l}\text { Outcome: The } \\
\text { number of } \\
\text { delirium } \\
\text { screenings } \\
\text { completed }\end{array}$ & $\begin{array}{l}\text { The baseline } \\
\text { for delirium } \\
\text { screening was } \\
0 \% \\
\text { compliance. } \\
\text { Four rounds of } \\
\text { audits with } \\
\text { feedback were } \\
\text { performed. The } \\
\text { compliance for } \\
\text { delirium } \\
\text { screening } \\
\text { increased to } \\
100 \%, 100 \% \text {, } \\
72 \% \text {, and } 72 \%, \\
\text { in that order, } \\
\text { for the four } \\
\text { rounds of audit } \\
\text { and feedback. } \\
\text { In addition, the } \\
\text { nurse's } \\
\text { knowledge on } \\
\text { the delirium } \\
\text { screening tool } \\
\text { was tested after } \\
\text { the audit and } \\
\text { feedback. The } \\
\text { nurse's } \\
\text { knowledge was } \\
\text { significantly } \\
\text { higher after the } \\
\text { intervention (p } \\
<0.001 \text { ) }\end{array}$ \\
\hline
\end{tabular}




\begin{tabular}{|c|c|c|c|c|c|c|}
\hline $\begin{array}{l}\text { Rohweder, C., Wangen, M., Black, M., Dolinger, H., } \\
\text { Wolf, M., O’Reilly, C., Brandt, H., \& Leeman, J. } \\
\text { (2019). Understanding quality improvement } \\
\text { collaboratives through an implementation science } \\
\text { lens. Preventive Medicine, 129(Supplement). } \\
\text { https://doi.org/10.1016/j.ypmed.2019.105859 }\end{array}$ & $\begin{array}{l}\text { Design: } \\
\text { Mixedmethod } \\
\text { quality } \\
\text { improvement } \\
\text { collaborative } \\
\text { Level: III Grade: } \\
\text { C. } \\
\text { Low quality }\end{array}$ & $\begin{array}{l}\text { Sample: } \\
\text { Patients, } \\
\text { ages 50-74 } \\
\text { years at nine } \\
\text { Federally } \\
\text { Qualified } \\
\text { Health } \\
\text { Centers in } \\
\text { North } \\
\text { Carolina } \\
\text { Sample size: } \\
31,338 \\
\text { patients }\end{array}$ & $\begin{array}{l}\text { Intervention: } \\
\text { Medical } \\
\text { professional at } \\
\text { participating } \\
\text { clinics were } \\
\text { provided } \\
\text { necessary } \\
\text { funding, } \\
\text { training, and } \\
\text { audit and } \\
\text { feedback } \\
\text { resources } \\
\text { Comparison: } \\
\text { Preintervention } \\
\text { data was } \\
\text { compared to } \\
\text { post } \\
\text { intervention } \\
\text { data }\end{array}$ & $\begin{array}{l}\text { Theoretical } \\
\text { foundation: } \\
\text { Implementation } \\
\text { science by } \\
\text { Powell and } \\
\text { Proctor (Powell } \\
\text { et al., 2015; } \\
\text { Proctor et al., } \\
\text { 2011) }\end{array}$ & $\begin{array}{l}\text { Outcome } \\
\text { definition: } \\
\text { Qualitative } \\
\text { comments } \\
\text { were } \\
\text { aggregated to } \\
\text { determine } \\
\text { themes. The } \\
\text { percentage of } \\
\text { patients } \\
\text { screened for } \\
\text { colorectal } \\
\text { cancer (CRC) } \\
\text { was the } \\
\text { quantitative } \\
\text { outcome. }\end{array}$ & $\begin{array}{l}\text { Qualitative } \\
\text { themes } \\
\text { included } \\
\text { motivated } \\
\text { engagement, } \\
\text { value of } \\
\text { personalized } \\
\text { support and } \\
\text { peer } \\
\text { networking. } \\
\text { Other } \\
\text { qualitative } \\
\text { themes } \\
\text { included } \\
\text { motivation to } \\
\text { perform } \\
\text { because of } \\
\text { audit and } \\
\text { feedback. } \\
\text { Quantitative } \\
\text { data showed a } \\
\text { 19.3\% increase } \\
\text { in CRC } \\
\text { screening. } \\
\text { Limitations } \\
\text { include risk for } \\
\text { selection bias, } \\
\text { lack of } \\
\text { randomization, } \\
\text { and lack of a } \\
\text { control group. } \\
\text { The study also } \\
\text { had a relatively } \\
\text { small sample } \\
\text { size }\end{array}$ \\
\hline $\begin{array}{l}\text { Singh, A., Danda, V., Van Swol, L., Scott, J. P., } \\
\text { Brandow, A. M., \& Panepinto, J. A. (2021). } \\
\text { Recommendation to reality: Closing the transcranial } \\
\text { Doppler screening gap for children with sickle cell }\end{array}$ & $\begin{array}{l}\text { Design: Single } \\
\text { medical center } \\
\text { Quality }\end{array}$ & $\begin{array}{l}\text { Sample: } \\
\text { Children } \\
\text { with sickle } \\
\text { cell disease }\end{array}$ & $\begin{array}{l}\text { Intervention: } \\
\text { Quarterly audit } \\
\text { and feedback }\end{array}$ & $\begin{array}{l}\text { Theoretical } \\
\text { foundation: } \\
\text { No }\end{array}$ & $\begin{array}{l}\text { Outcome: } \\
\text { Increase } \\
\text { transcranial } \\
\text { doppler } \\
\text { (TCD) }\end{array}$ & $\begin{array}{l}\text { Post } \\
\text { intervention } \\
\text { TCD screening }\end{array}$ \\
\hline
\end{tabular}




\begin{tabular}{|c|c|c|c|c|c|c|}
\hline & & $\begin{array}{l}\text { that } \\
\text { received }\end{array}$ & $\begin{array}{l}\text { to share } \\
\text { overdue }\end{array}$ & $\begin{array}{l}\text { conceptual or } \\
\text { theoretical }\end{array}$ & & $\begin{array}{l}\text { rates increased } \\
\text { from } 63 \% \text { to }\end{array}$ \\
\hline $\begin{array}{l}\text { anemia. Pediatric Blood \& Cancer, 68(2), e28831. } \\
\underline{\text { https://doi.org/10.1002/pbc.28831 }}\end{array}$ & $\begin{array}{l}\text { Improvement } \\
\text { Study } \\
\text { Level: III Grade: } \\
\text { C. } \\
\text { Low quality }\end{array}$ & $\begin{array}{l}\text { care at a } \\
\text { single } \\
\text { tertiary care } \\
\text { facility - } \\
\text { Sample } \\
\text { Size: } \\
114 \text { children }\end{array}$ & $\begin{array}{l}\text { screening with } \\
\text { care team for } \\
\text { follow-up } \\
\text { Comparison: } \\
\text { Preintervention } \\
\text { comparison } \\
\text { was used }\end{array}$ & $\begin{array}{l}\text { framework } \\
\text { was mentioned }\end{array}$ & $\begin{array}{l}\text { screening in } \\
\text { children with } \\
\text { sickle cell } \\
\text { anemia as } \\
\text { recorded in } \\
\text { the electronic } \\
\text { health record } \\
\text { TDC registry }\end{array}$ & $\begin{array}{l}79 \% . \\
\text { Limitations } \\
\text { include } \\
\text { relatively small } \\
\text { sample size and } \\
\text { that it is limited } \\
\text { to a single } \\
\text { institution. } \\
\text { Results may } \\
\text { not be } \\
\text { generalizable. }\end{array}$ \\
\hline $\begin{array}{l}\text { Weiss, D., Dunn, S. I., Sprague, A. E., Fell, D. B., } \\
\text { Grimshaw, J. M., Darling, E., Graham, I. D., } \\
\text { Harrold, } \\
\text { J., Smith, G. N., Peterson, W. E., Reszel, J., Lanes, } \\
\text { A., Walker, M. C., \& Taljaard, M. (2018). Effect of } \\
\text { a population-level performance dashboard } \\
\text { intervention on maternal-newborn outcomes: An } \\
\text { interrupted time series study. BMJ QUALITY \& } \\
\text { SAFETY, 27(6), 425-436. } \\
\text { https://doi.org/10.1136/bmjqs-2017-007361 }\end{array}$ & $\begin{array}{l}\text { Design: } \\
\text { Quasiexperimental } \\
\text { Level: II Grade: } \\
\text { B. } \\
\text { Good }\end{array}$ & $\begin{array}{l}\text { Sample: } \\
\text { Live births } \\
\text { at } 94 \\
\text { hospitals in } \\
\text { Ontario } \\
\text { Sample size: } \\
728,109 \text { live } \\
\text { births }\end{array}$ & $\begin{array}{l}\text { Intervention: } \\
\text { Dashboard } \\
\text { audit and } \\
\text { feedback } \\
\text { intervention } \\
\text { Control: } \\
\text { Performance } \\
\text { indicators not } \\
\text { contained } \\
\text { within the } \\
\text { dashboard }\end{array}$ & $\begin{array}{l}\text { Theoretical } \\
\text { foundation: No } \\
\text { theory was } \\
\text { mentioned but } \\
\text { Ramsay's } \\
\text { framework for } \\
\text { assessing } \\
\text { quality was } \\
\text { used }\end{array}$ & $\begin{array}{l}\text { Outcome } \\
\text { definition: } \\
\text { The number } \\
\text { of group B } \\
\text { streptococcus } \\
\text { completed per } \\
100,000 \text { live } \\
\text { births }\end{array}$ & $\begin{array}{l}\text { Group B } \\
\text { streptococcus } \\
\text { screening } \\
\text { significantly } \\
\text { increased by } \\
2.8 \%(95 \% \text { CI } \\
2.2 \text { to } 3.5)\end{array}$ \\
\hline
\end{tabular}


Figure 1

PRISMA diagram of literature search results

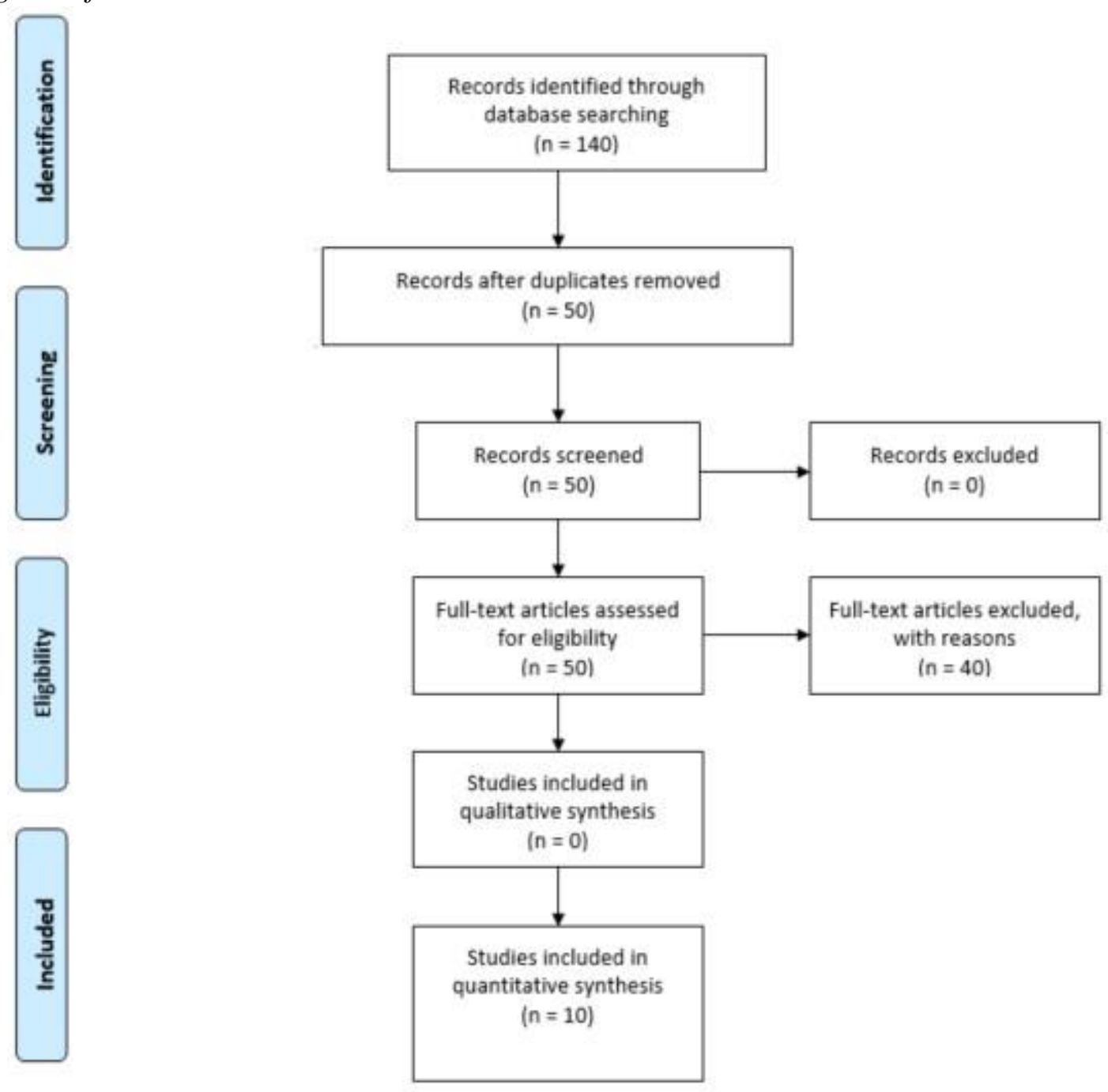

From: Moher D. Liberati A, Tetzlaff J, Altman DG, The PRISMA Group (2009). Preferred Reporting /items for Systematic Reviews and Meta-Analyses: The PRISMA Statement. PLoS Med 6(7): e1000097. Doi: 10.1 371/journal.pmed1000097 


\section{Appendix A}

SWOT Analysis of Setting for DNP Project

Strengths

Weaknesses

Opportunities

Threats

\begin{tabular}{|c|c|c|c|}
\hline $\begin{array}{c}\text { Structured healthcare } \\
\text { system }\end{array}$ & High staff turnover & $\begin{array}{c}\text { Forced-function built into } \\
\text { EHR for lung screening }\end{array}$ & Competing priorities \\
\hline $\begin{array}{c}\text { Clearly defined chain of } \\
\text { command and roles }\end{array}$ & Staffing vacancies & $\begin{array}{c}\text { Hard-wire process into } \\
\text { daily workflow }\end{array}$ & Staff turnover \\
\hline $\begin{array}{c}\text { Strong interprofessional } \\
\text { collaboration }\end{array}$ & $\begin{array}{c}\text { No forced function built } \\
\text { into EHR for lung } \\
\text { screening }\end{array}$ & $\begin{array}{c}\text { Staff education on lung } \\
\text { screening benefits, risks, } \\
\text { alternatives, and eligibility } \\
\text { criteria }\end{array}$ & A lack of accountability \\
\hline $\begin{array}{c}\text { System level support for } \\
\text { project success }\end{array}$ & $\begin{array}{c}\text { Lack of staff proficiency: } \\
\text { (Lung Nodule Coordinator, } \\
\text { primary care clinic } \\
\text { director, medical assistants, } \\
\text { medical providers) }\end{array}$ & $\begin{array}{c}\text { Patient education on risk, } \\
\text { lung cancer screening }\end{array}$ & (emerging healthcare \\
issues)
\end{tabular}




\section{Appendix B}

Outline of PowerPoint presentation for medical providers and clinic office staff

1. Title Slide: Project to Promote Lung Screening to Save Lives
a. Name of student
b. Name of academic institution

2. Slide 2: Significance of problem and background of lung cancer in the US

a. Number of annual lung cancer deaths

b. Lung cancer deaths compared to colon, breast, and prostate cancer

3. Slide 3: Economic impact of lung cancer in the US
a. Annual spending
b. Initial cost of lung cancer treatment
c. Cost of continued care for lung cancer
d. Cost for end-of-life care
e. Economic impact for loss of productivity

4. Slide 4: Cost breakdown for lung cancer per patient
a. Initial surgical cost
b. First six months of treatment cost
c. Cost of prescription drugs
d. Cost during terminal phase

5. Slide 5: Smoking and lung cancer information for city in which project setting is located a. Smoking rates

b. Number of lung screen orders from respective clinic in 2020

6. Slide 6: Risks to patients associated with lung cancer screening
a. False positives 
b. Radiation exposure

c. Emotional distress

d. Unneeded invasive procedures and complications from these procedures

7. Slide 7: Benefits of lung cancer screening to patients
a. Lower mortality rates
b. Number of lives saved
c. No alternative lung cancer screen
d. More favorable prognosis

8. Slide 8: Eligibility criteria for lung cancer screening
a. Age criteria
b. Absence of lung cancer symptoms
c. Smoking history and pack-year
d. Willingness to undergo lung cancer treatment

9. Slides 9 through 11: Instructions to medical assistants (MAs) for placing lung cancer screen order in electronic health record (EHR)

10. Slides 12 through 16: Instructions for medical providers for placing lung cancer screen orders in EHR

11. Slide 17: Reminder to providers and overview of shared decision-making session for lung cancer screening

12. Slide 18: Overview of goals and intervention of DNP project to increase lung cancer screening

13. Slide 19: Overview of audit and feedback for improving cancer screening rates

14. Slide 20: Questions - contact information for DNP students if clinic staff has questions, comments, or concerns

15. Slide 21-23: References 


\section{Appendix C}

Overview of Project Interventions

Intervention

Person (s) Responsible

Week of Project Intervention

\begin{tabular}{|c|c|c|}
\hline $\begin{array}{l}\text { Provide lung screen awareness } \\
\text { PowerPoint to providers and } \\
\text { medical assistants (MAs) }\end{array}$ & Project manager & Week 1 \\
\hline $\begin{array}{l}\text { Educate providers and MAs } \\
\text { about use of lung cancer } \\
\text { screening audit tool (LCSAT) }\end{array}$ & Manager of care coordination & Week 1 \\
\hline $\begin{array}{l}\text { Distribute LCSATs to all patient } \\
\text { rooms for use (ensure rooms stay } \\
\text { stocked with this form) }\end{array}$ & Clinic manager & $\begin{array}{l}\text { Each week of project } \\
\text { intervention }\end{array}$ \\
\hline $\begin{array}{l}\text { Validate that LCSATs are } \\
\text { completed on smokers/former } \\
\text { smokers ages } 55-80 \text { years }\end{array}$ & Providers & Throughout project intervention \\
\hline $\begin{array}{l}\text { Order lung screen for eligible } \\
\text { patients after shared } \\
\text { decisionmaking and patient } \\
\text { consents }\end{array}$ & Providers & Throughout project intervention \\
\hline $\begin{array}{l}\text { Record refusal reason of lung } \\
\text { screen on LCSATs for eligible } \\
\text { patients }\end{array}$ & Providers & Throughout project intervention \\
\hline $\begin{array}{l}\text { Collect utilized LCSATs at end } \\
\text { of each clinic day and place in } \\
\text { designated storage area }\end{array}$ & Clinic manager & $\begin{array}{l}\text { Each week of project } \\
\text { intervention }\end{array}$ \\
\hline $\begin{array}{l}\text { Audit LCSATs (no less than } \\
\text { weekly) and record findings on } \\
\text { data collection tool }\end{array}$ & Project manager & $\begin{array}{l}\text { Each week of project } \\
\text { intervention }\end{array}$ \\
\hline $\begin{array}{l}\text { Aggregate audited data for } \\
\text { weekly feedback (no less than } \\
\text { weekly) }\end{array}$ & Project manager & $\begin{array}{l}\text { Each week of project } \\
\text { intervention }\end{array}$ \\
\hline $\begin{array}{l}\text { Provide feedback on data to } \\
\text { providers and clinic staff; } \\
\text { Feedback must include data that } \\
\text { is provider-specific (emails, } \\
\text { communication boards, staff } \\
\text { meetings) }\end{array}$ & $\begin{array}{l}\text { Project manager, manager of } \\
\text { care coordination, and clinic } \\
\text { manager }\end{array}$ & $\begin{array}{l}\text { No less that each week of project } \\
\text { and during previously scheduled } \\
\text { staff meetings }\end{array}$ \\
\hline $\begin{array}{l}\text { Celebrate short-term wins } \\
\text { (increased documentation } \\
\text { compliance, increase lung scans) }\end{array}$ & $\begin{array}{l}\text { Project manager, manager of } \\
\text { care coordination, clinic } \\
\text { manager, providers, clinic staff }\end{array}$ & $\begin{array}{l}\text { Each week of project } \\
\text { intervention }\end{array}$ \\
\hline $\begin{array}{l}\text { Provide project summary to } \\
\text { clinic staff, providers, key } \\
\text { stakeholders }\end{array}$ & Project manager & $\begin{array}{l}\text { This will occur after evaluation } \\
\text { phase of project }\end{array}$ \\
\hline $\begin{array}{l}\text { Ongoing audit and feedback of } \\
\text { lung screen data and } \\
\text { documentation }\end{array}$ & Manager of care coordination & $\begin{array}{l}\text { Ongoing after cessation of } \\
\text { project }\end{array}$ \\
\hline
\end{tabular}




\section{Appendix D}

Patient Brochure (page 1 of 2)

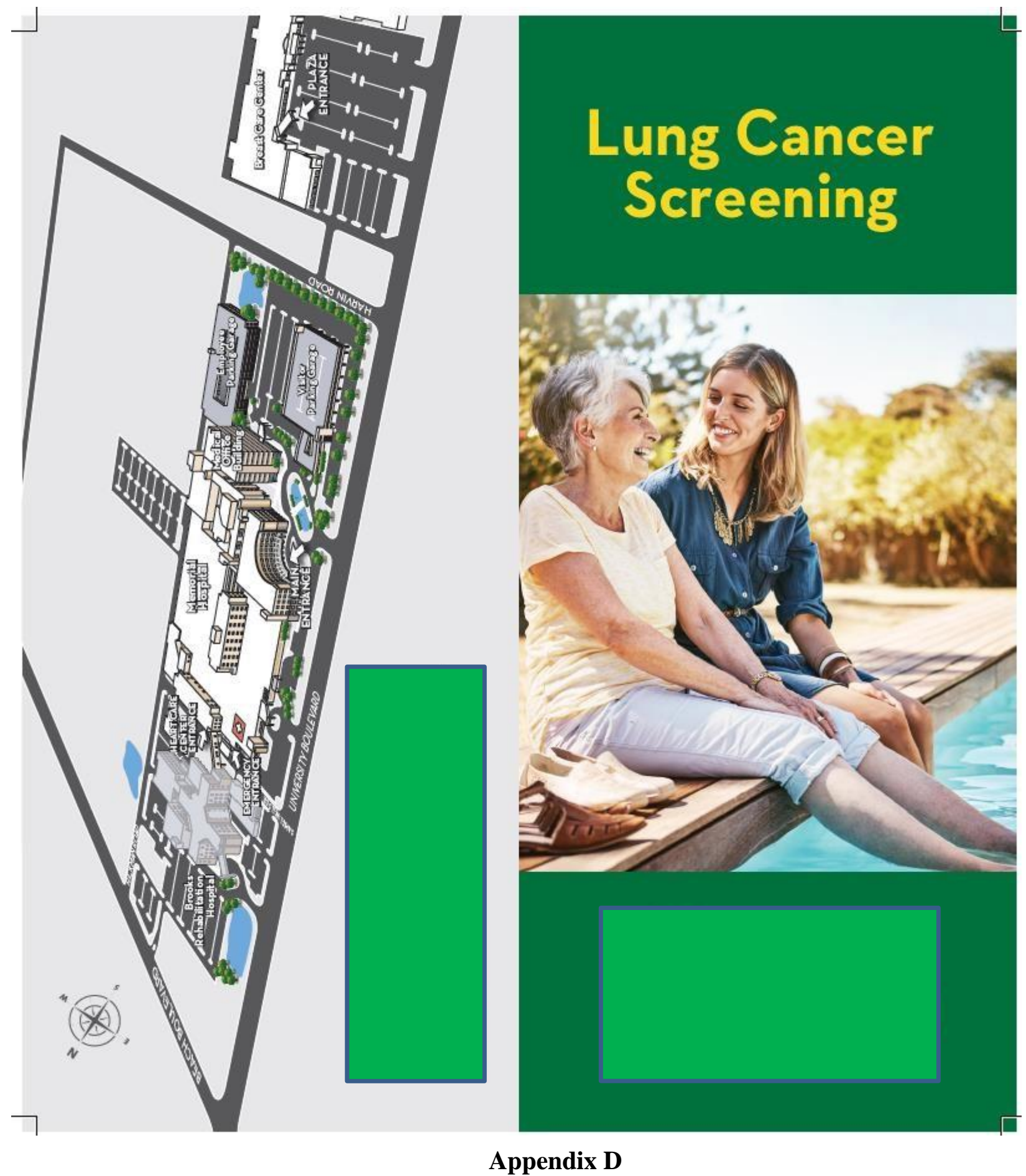

Patient Brochure (page 2 of 2) 


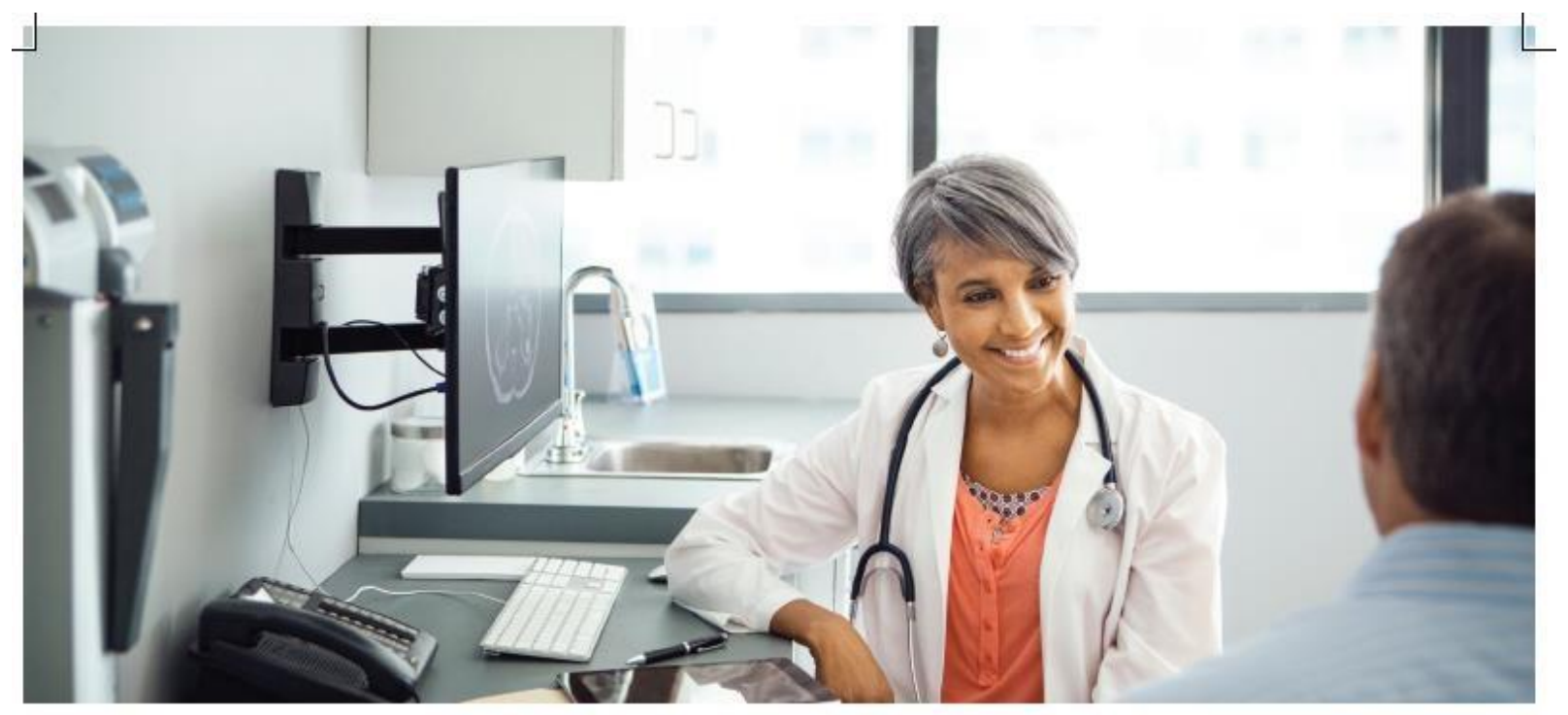

What is a Lung Cancer Screening?

It's a safe, comfortable, convenient way to gain peace of mind by detecting lung cancer earlier. Even if you feel like you are in good health, this is an opportunity to get screened before any symptoms show up. A key to the successful treatment of lung cancer is early detection.

\section{How Does it Work?}

Each screening is done in a comfortable setting with a low dose CT lung scan - a painless, noninvasive procedure that provides detailed three-dimensional images of your lungs. The entire appointment should take approximately 20 minutes. Our radiologist will review the low dose $x$-ray images for any suspicious areas that need further attention. Additional testing or treatment may be recommended if needed.
Is the Lung Cancer Screening Right for Me?

High Risk Criteria

- Ages 55-80 with a 30 pack year* smoking history

- Either a current smoker or smoker who quit in the past 15 years

- No symptoms of lung cancer

-A pack year is the number of packs smoked per day multiplied by the number of years smoked. For example: 1.5 packs a day $x 20$ years $=30$ pack years.

How Do I Schedule a Screening?

The low dose CT screening is available at either Memorial Hospital or the outpatient Plaza. Call (904) 702-1150 today to schedule an appointment at the location most convenient for you.

\section{What Does it Cost?}

Please call your insurance company to verify coverage under your plan. If your insurance does not cover this as a preventative screening, the cash, self-pay price of $\$ 199$ is available and covers the radiologist's fee.

\section{Appendix E}

Lung Cancer Screening Audit Tool

\section{Lung Cancer Screening Checklist}


For Patients 55-80 years old (WITH A CURRENT OR FORMER SMOKING HISTORY)

Please complete the following questions:

1. The patient IS age 55-80: Yes No

2. The patient $\underline{\mathbf{I S}}$ a smoker $\underline{\mathrm{OR}}$ has a history of smoking: Yes No

3. If the patient is a former smoker, did he/she quit smoking within the past 15 years (quit since year 2006)? Yes No

4. The patient has a pack-year history $\geq 30 *$ : Yes No

5. The patient is WITHOUT all the following symptoms: fever, chest pain, new shortness of breath, new or changing cough, coughing up blood, or unexplained significant weight loss? Yes No

6. The patient has $\underline{\text { NO }}$ history of lung cancer: Yes No

7. The patient has NOT had a CT of the chest in the last 11 months: Yes No

8. The patient $\underline{\mathbf{I S}}$ willing to undergo treatment if lung cancer is detected: Yes No If you answered $\underline{Y E S}$ to $\underline{A L L}$ of the above questions, your patient IS eligible for lung cancer screening. Please complete shared decision-making and lung screen order.

Patient's Age:

Patient's Sex Assigned at Birth:

Physician's Name:

Today's date:

If patient eligible for lung cancer screening refuses screening, please identify reason below:

\footnotetext{
*Pack-year history is calculated by multiplying the number of cigarette packs per day by the number of years that the person smoked.
}

These forms are to be given to the clinic's manager before the end of each day. 


\section{Appendix F}

Data Collection Tool

(page 1 of 3 )

\begin{tabular}{|l|l|l|l|l|l|}
\hline Week \# and date: & $\begin{array}{c}\text { Audit } \\
\text { Number }\end{array}$ & $\begin{array}{c}\text { Audit } \\
\text { Number }\end{array}$ & $\begin{array}{c}\text { Audit } \\
\text { Number }\end{array}$ & $\begin{array}{c}\text { Audit } \\
\text { Number }\end{array}$ & $\begin{array}{c}\text { Audit } \\
\text { Number }\end{array}$ \\
\hline Provider & & & & & \\
\hline Age & & & & & \\
\hline Gender & & & & & \\
\hline Smoke history & & & & & \\
\hline Current Smoker & & & & & \\
\hline Years quit & & & & & \\
\hline Pack-year history & & & & & \\
\hline Lung cancer history & & & & & \\
\hline $\begin{array}{l}\text { Willing to have lung cancer } \\
\text { treatment }\end{array}$ & & & & & \\
\hline Active lung cancer symptoms & & & & & \\
\hline CT Scan in last 11 months & & & & & \\
\hline LDCT ordered & & & & & \\
\hline LDCT Completed & & & & \\
\hline
\end{tabular}


Appendix F

Data Collection Tool

(page 2 of 3 )

\begin{tabular}{|c|c|c|c|}
\hline & Week 1 & Week 2 & Week 3 \\
\hline Dates data collected & & & \\
\hline Dates of Visits to clinic & & & \\
\hline Total \# Patients Seen & & & \\
\hline Patients Age 55-80 & & & \\
\hline Number of Audited Screening Tools & & & \\
\hline Male Patients & & & \\
\hline Female Patients & & & \\
\hline Current Smokers & & & \\
\hline Male current/former smokers & & & \\
\hline Female current/former smokers & & & \\
\hline Total of current/former smokers & & & \\
\hline Total Percent of patients who smoked & & & \\
\hline Percent of men who smoked & & & \\
\hline Percent of women who smoked & & & \\
\hline Lung Cancer Hx & & & \\
\hline Number of patients who quit smoking & & & \\
\hline Quit $\leq 15$ years & & & \\
\hline Quit $\geq 15$ years & & & \\
\hline Years quit documented (former smoker) & & & \\
\hline Years quit not documented (former smokers) & & & \\
\hline Pack-yr Hx $\geq 30$ & & & \\
\hline Pack-yr Hx $\leq 30$ & & & \\
\hline Pack-years documented (current/former) & & & \\
\hline Pack-years not documented (current/former) & & & \\
\hline Smokers Asympt. Lung Cancer & & & \\
\hline Lung Ca sx not documented on potential LDCT & & & \\
\hline Smokers w/t CT $\leq 11$ months & & & \\
\hline Patients meeting LDCT Criteria & & & \\
\hline
\end{tabular}




\section{Appendix F}

Data Collection Tool

\begin{tabular}{|l|l|l|l|}
\hline \# of Completed LDCT Assessments & & & \\
\hline \# of incomplete LDCT Assessments & & & \\
\hline \# of completed SDM for LDCT & & & \\
\hline \# of LDCT orders & & & \\
\hline \# of completed LDCT Scans & & & \\
\hline \# Patients refusing scan & & & \\
\hline Number of potential LDCT patients & & & \\
\hline
\end{tabular}

(page 3 of 3 )

\begin{tabular}{|l|l|l|l|}
\hline Documentation Compliance per MD & & & \\
\hline Provider 1 & & & \\
\hline Asked if Current smoker or smoking hx & & & \\
\hline Number of current/former smokers identified & & & \\
\hline Number of years quit & & & \\
\hline Pack-year history & & & \\
\hline LDCT orders & & & \\
\hline Provider $\mathbf{2}$ & & & \\
\hline Asked if Current smoker or smoking hx & & & \\
\hline Number of current/former smokers identified & & & \\
\hline Number of years quit & & & \\
\hline Pack-year history & & & \\
\hline LDCT orders & & & \\
\hline Provider 3 & & & \\
\hline Asked if Current smoker or smoking hx & & & \\
\hline Number of current/former smokers identified & & & \\
\hline Number of years quit & & & \\
\hline Pack-year history & & & \\
\hline LDCT orders & & & \\
\hline Provider 4 & & & \\
\hline Asked if Current smoker or smoking hx & & & \\
\hline
\end{tabular}




\section{Appendix F}

Data Collection Tool

\begin{tabular}{|l|l|l|l|}
\hline Number of current/former smokers identified & & & \\
\hline Number of years quit & & & \\
\hline Pack-year history & & & \\
\hline LDCT orders & & & \\
\hline Provider 5 & & & \\
\hline Asked if Current smoker or smoking hx & & & \\
\hline Number of current/former smokers identified & & & \\
\hline Number of years quit & & & \\
\hline Pack-year history & & & \\
\hline LDCT orders & & & \\
\hline
\end{tabular}




\section{Appendix G}

Benchmarking Data Measures

\begin{tabular}{|c|c|c|c|c|c|}
\hline Objective & Initiative & Measure & Target & $\begin{array}{l}\text { Responsible } \\
\text { Party }\end{array}$ & $\begin{array}{l}\text { Reporting } \\
\text { Frequency }\end{array}$ \\
\hline Outcome & $\begin{array}{l}\text { Completed } \\
\text { LDCT lung } \\
\text { screen }\end{array}$ & $\begin{array}{l}\text { Completed } \\
\text { LDCT lung } \\
\text { screen test }\end{array}$ & $\begin{array}{l}100 \% \text { of } \\
\text { patients who } \\
\text { meet criteria get } \\
\text { LDCT lung } \\
\text { screen }\end{array}$ & Project Manager & Weekly \\
\hline Process & $\begin{array}{l}\text { Lung screen } \\
\text { eligibility } \\
\text { assessed }\end{array}$ & $\begin{array}{l}\text { Completed } \\
\text { eligibility } \\
\text { assessment } \\
\text { and LDCT } \\
\text { lung screen } \\
\text { order }\end{array}$ & $\begin{array}{l}100 \% \\
\text { completion for } \\
\text { smokers/former } \\
\text { smokers ages } 55 \\
-80 \text { years }\end{array}$ & Project Manager & Weekly \\
\hline Balancing & $\begin{array}{l}\text { Audit and } \\
\text { feedback to } \\
\text { medical } \\
\text { providers } \\
\text { and office } \\
\text { staff }\end{array}$ & $\begin{array}{l}\text { How many } \\
\text { lung cancer } \\
\text { screen tools } \\
\text { audited for } \\
\text { clinic }\end{array}$ & $\begin{array}{l}\text { At least } 100 \\
\text { audits each } \\
\text { week }\end{array}$ & Project Manager & Weekly \\
\hline Sustainability & $\begin{array}{l}\text { Ongoing } \\
\text { audit and } \\
\text { feedback of } \\
\text { lung screen } \\
\text { eligibility } \\
\text { assessment } \\
\text { by clinic } \\
\text { staff }\end{array}$ & $\begin{array}{l}\text { How many } \\
\text { lung cancer } \\
\text { screen tools } \\
\text { audited for } \\
\text { clinic }\end{array}$ & $\begin{array}{l}100 \% \\
\text { compliance }\end{array}$ & $\begin{array}{l}\text { Manager of care } \\
\text { coordination }\end{array}$ & $\begin{array}{l}30 \text { days after the project } \\
\text { completion date }\end{array}$ \\
\hline
\end{tabular}


Appendix $\mathbf{H}$

Project Schedule Timeline

\begin{tabular}{|c|c|c|c|c|c|c|c|c|c|c|c|c|c|c|c|c|c|c|c|c|c|c|c|c|}
\hline & \multicolumn{8}{|c|}{ NUR7801 } & \multicolumn{8}{|c|}{ NUR7802 } & \multicolumn{8}{|c|}{ NUR7803 } \\
\hline 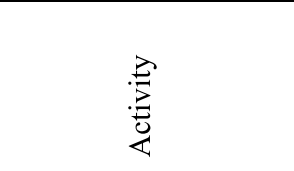 & $\frac{7}{3}$ & $\frac{m}{y}$ & $\begin{array}{l}n \\
\frac{y}{8} \\
3\end{array}$ & $\frac{5}{8}$ & $\begin{array}{l}a \\
\frac{y}{0} \\
3\end{array}$ & $\begin{array}{l}\exists \\
y \\
\bar{y} \\
3\end{array}$ & $\begin{array}{l}\frac{m}{y} \\
\frac{y}{0} \\
\frac{1}{3}\end{array}$ & $\frac{n}{\frac{n}{8}}$ & $\frac{\bar{y}}{3}$ & $\begin{array}{l}m \\
\frac{n}{3} \\
3\end{array}$ & $\begin{array}{l}n \\
\frac{n}{0} \\
3\end{array}$ & $\frac{5}{3}$ & $\begin{array}{l}a \\
\frac{a}{0} \\
3\end{array}$ & $\begin{array}{l}= \\
\frac{y}{8} \\
3\end{array}$ & $\begin{array}{l}n \\
\frac{y}{8} \\
\frac{d}{3}\end{array}$ & $\begin{array}{l}\frac{n}{4} \\
\frac{y}{8} \\
3\end{array}$ & $\begin{array}{l}\vec{y} \\
\frac{y}{3} \\
3\end{array}$ & $\begin{array}{l}n \\
\frac{n}{8} \\
3 \\
3\end{array}$ & $\begin{array}{l}n \\
\frac{y}{0} \\
0 \\
3\end{array}$ & $\frac{y}{3}$ & $\frac{a}{3}$ & $\begin{array}{l}= \\
\frac{y}{8} \\
3\end{array}$ & $\begin{array}{l}\frac{m}{y} \\
\frac{y}{8} \\
3\end{array}$ & $\begin{array}{l}\frac{n}{y} \\
\frac{\pi}{8} \\
3\end{array}$ \\
\hline $\begin{array}{l}\text { Meet with preceptor } \\
\text { and identify practice } \\
\text { problem }\end{array}$ & & & & & & & & & & & & & & & & & & & & & & & & \\
\hline $\begin{array}{l}\text { Review literature to } \\
\text { determine background } \\
\text { and significance of } \\
\text { problem, EBP } \\
\text { framework and change } \\
\text { theory }\end{array}$ & & & & & & & & & & & & & & & & & & & & & & & & \\
\hline $\begin{array}{l}\text { Review of literature } \\
\text { related to EBP } \\
\text { intervention. Establish } \\
\text { search strategy, } \\
\text { inclusion/exclusion } \\
\text { criteria, and appraise } \\
\text { literature }\end{array}$ & & & & & & & & & & & & & & & & & & & & & & & & \\
\hline
\end{tabular}




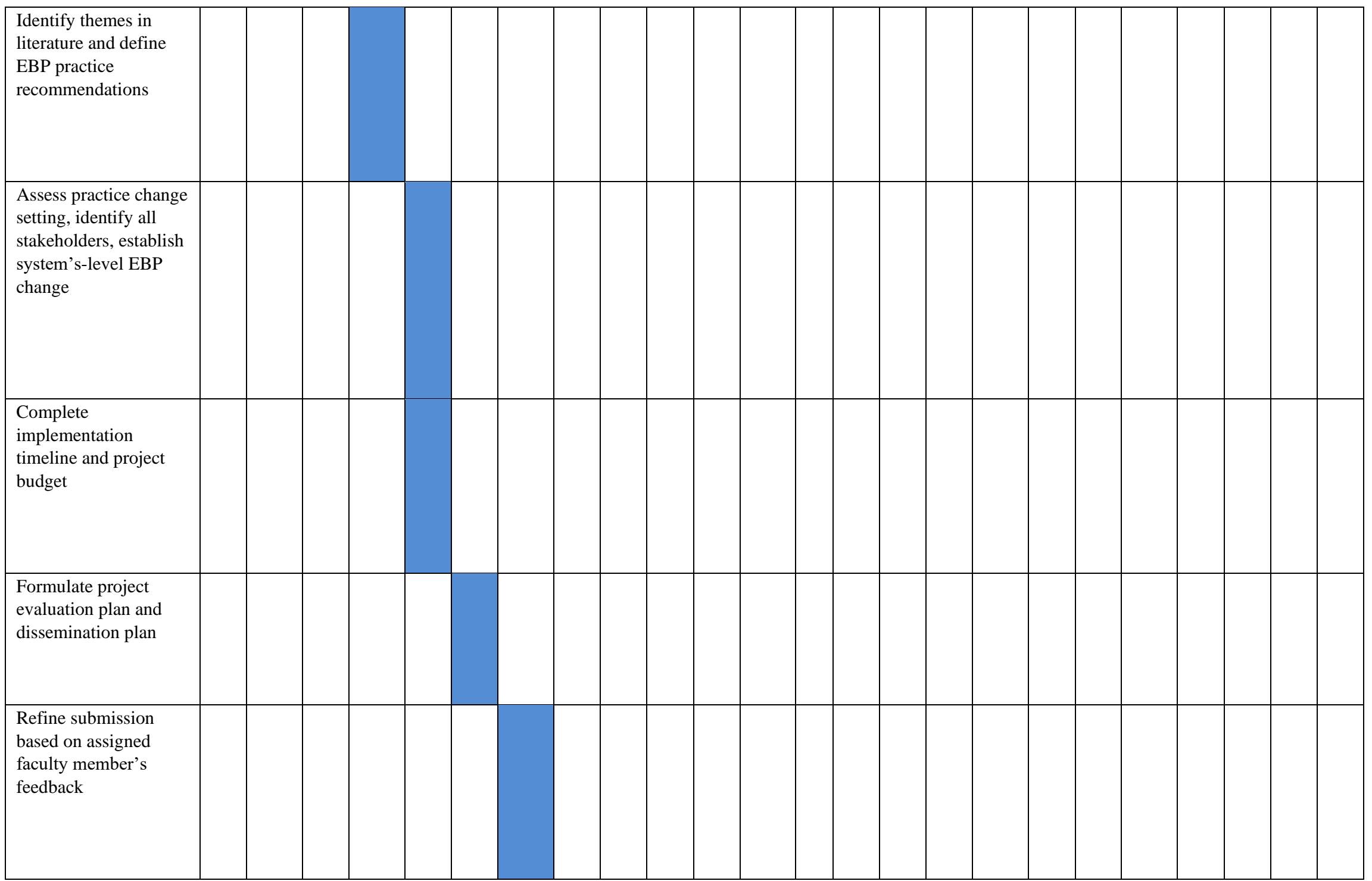




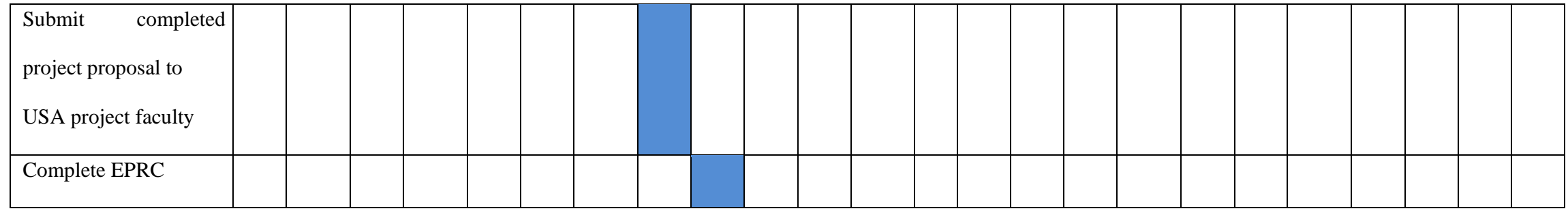

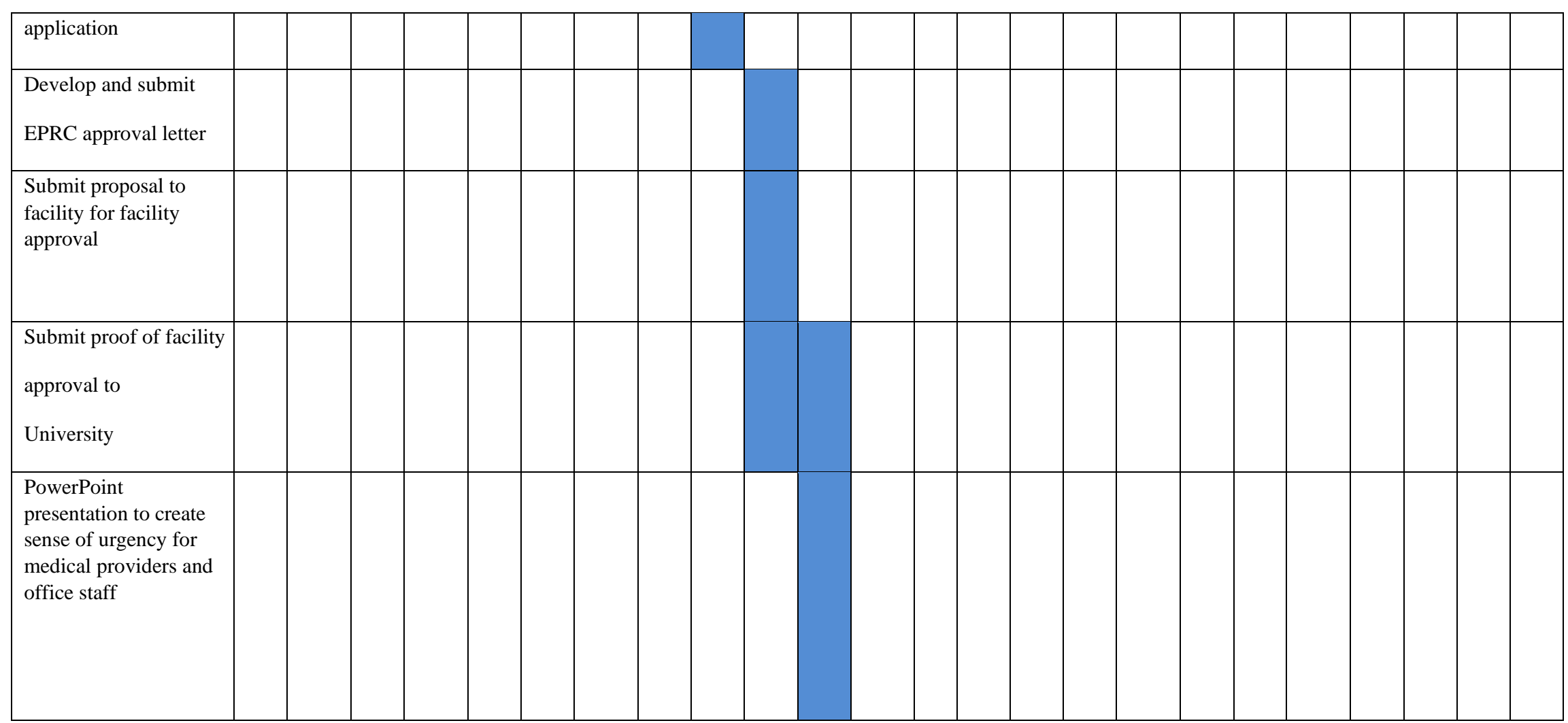




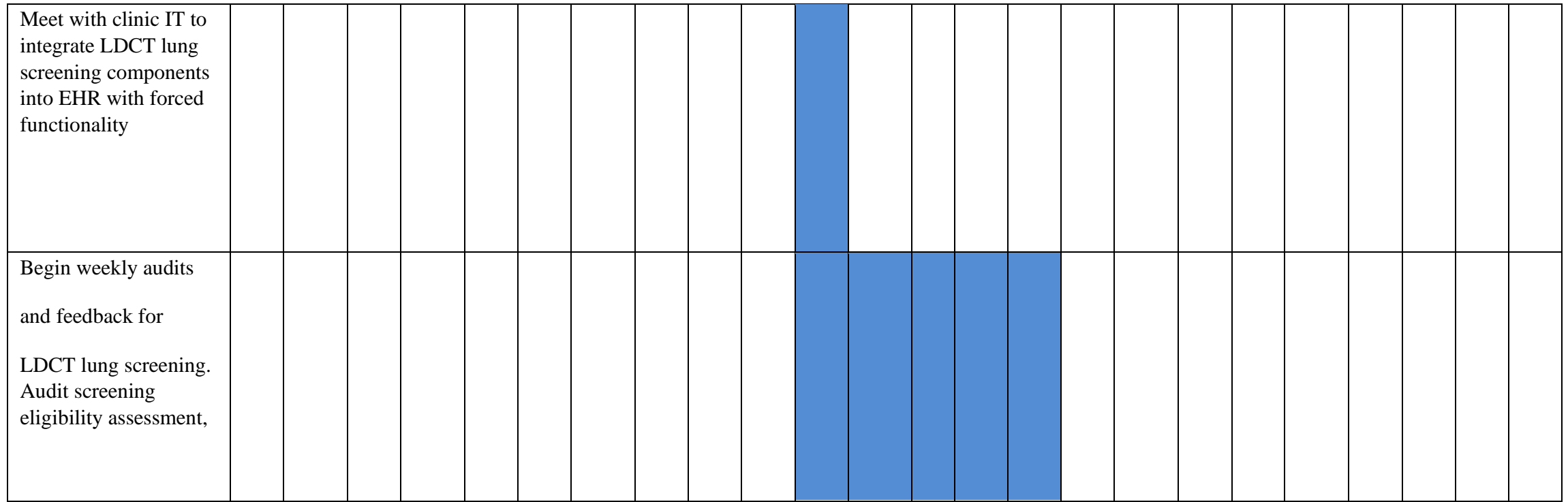

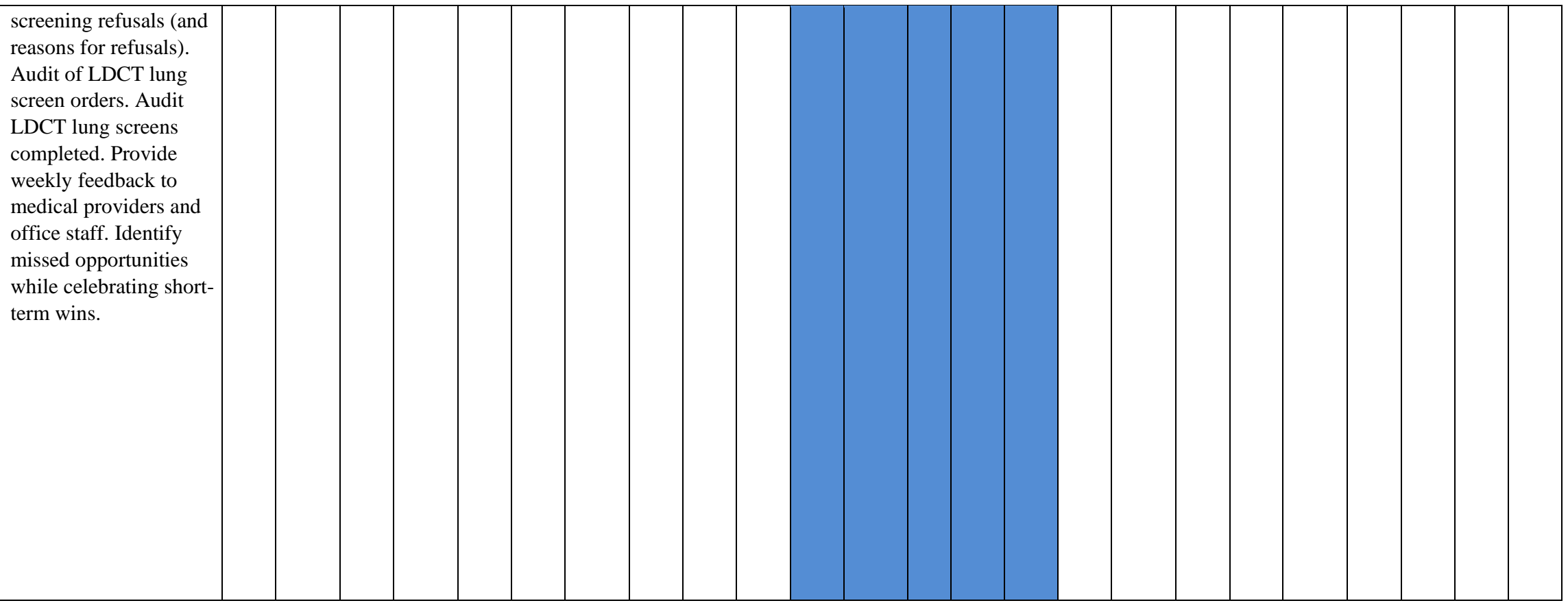




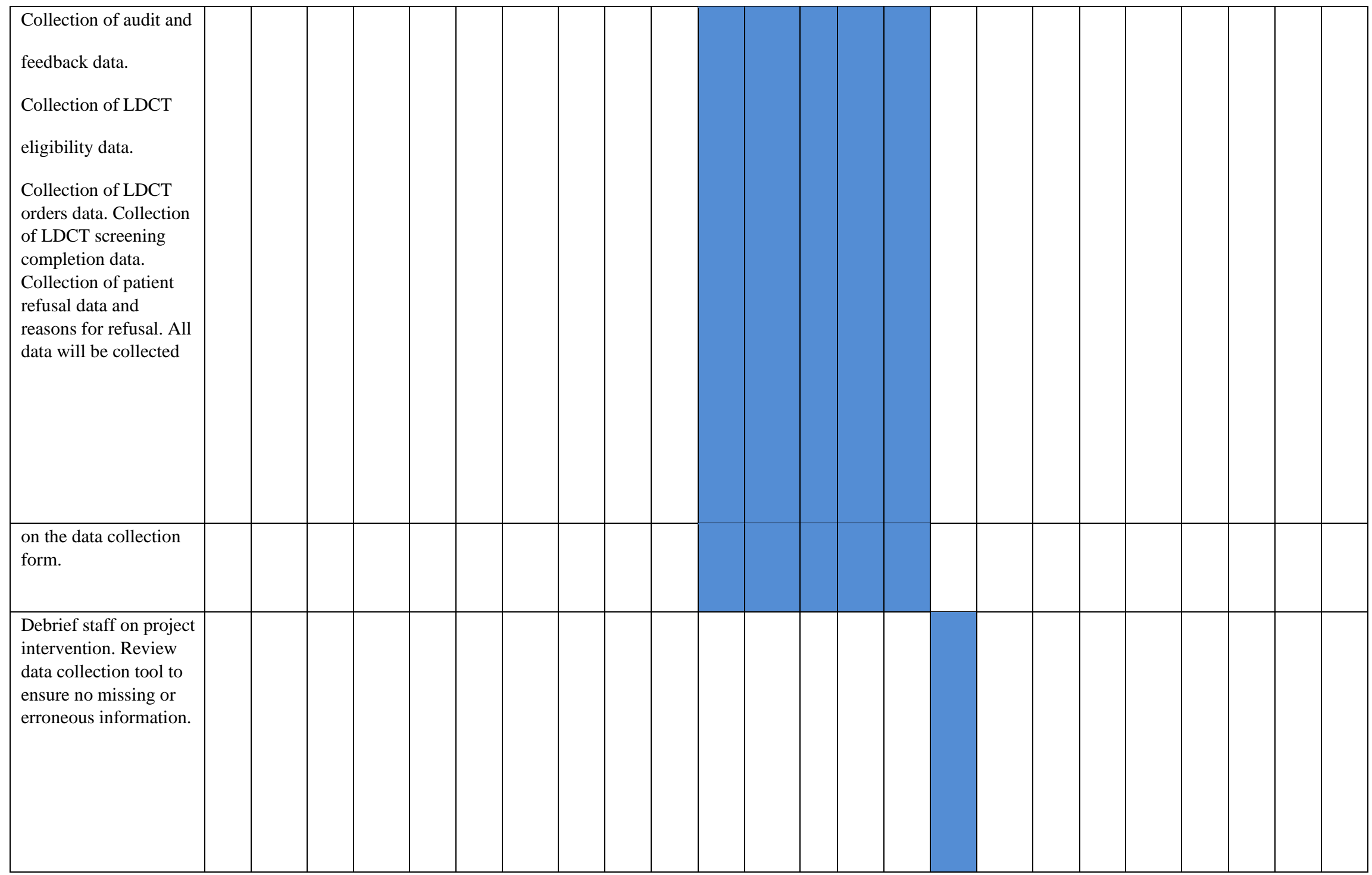




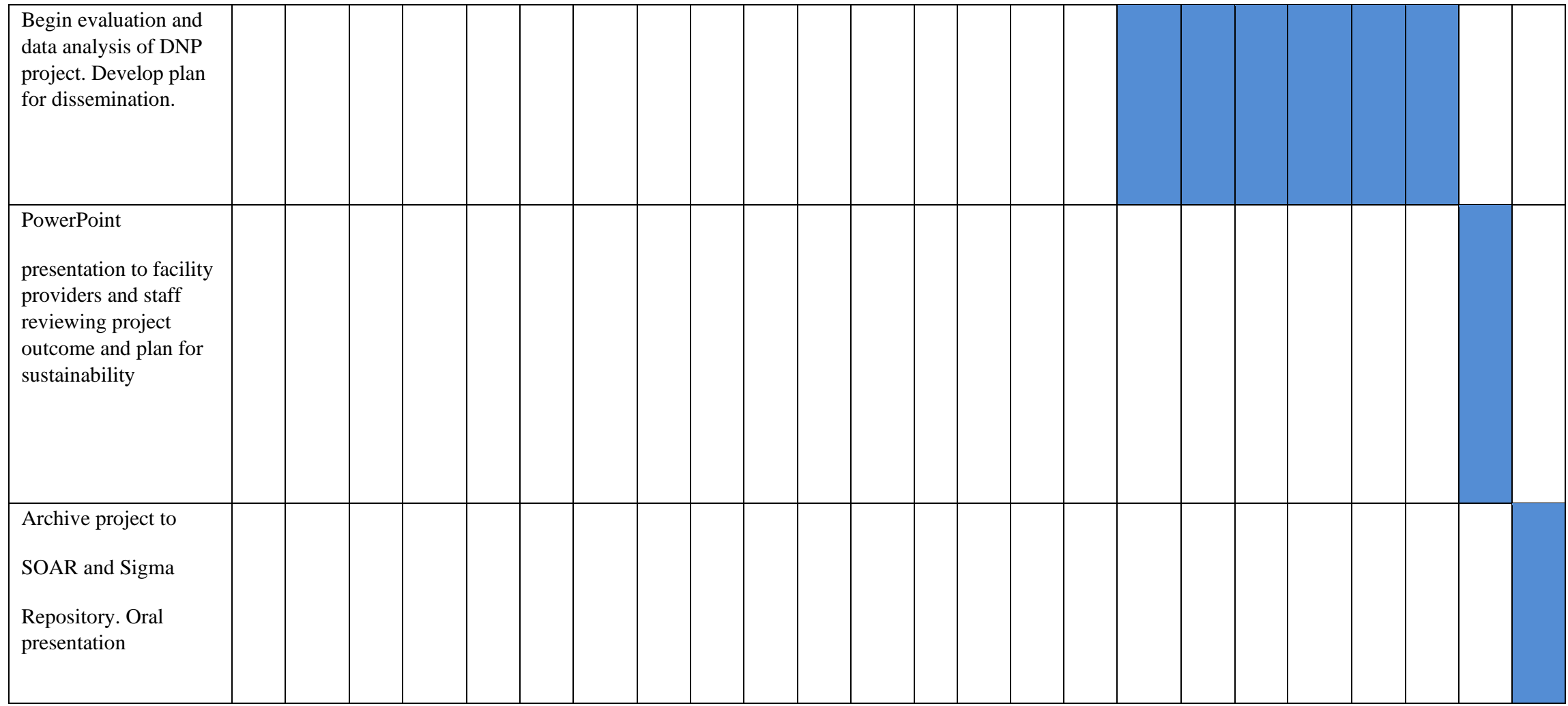




\section{Appendix I}

Table I1.

Frequency Table for Patients Seen at Clinic per Project Phase with number of LDCT Audit Forms and the number of LDCT Orders

\begin{tabular}{lrr}
\hline Variable & $n$ & $\%$ \\
\hline Number of Patients per Project Phase & & \\
Baseline & 1218 & 32.07 \\
Intervention & 1383 & 36.41 \\
Evaluation & 1197 & 31.52 \\
Missing & 0 & 0.00 \\
LDCT Audit Forms Submitted per Patient & & \\
No & 3545 & 93.34 \\
Yes & 253 & 6.66 \\
Missing & 0 & 0.00 \\
LDCT Lung Cancer Screen Ordered & & \\
Yes & 19 & 0.50 \\
No & 3779 & 99.50 \\
Missing & 0 & 0.00 \\
\hline
\end{tabular}

Note. Due to rounding errors, percentages may not equal $100 \%$.

\section{Table I2.}

Frequency Table for Number of Patients that Met LDCT Lung Cancer Screening Criteria

\begin{tabular}{lrr}
\hline Variable & $n$ & $\%$ \\
\hline Did patient meet eligibility criteria for LDCT lung cancer screening? & & \\
Unable to determine & 9 & 3.23 \\
No & 235 & 84.23 \\
Yes & 35 & 12.54 \\
Missing & 0 & 0.00
\end{tabular}

Note. Due to rounding errors, percentages may not equal $100 \%$. 


\section{Table I3.}

Frequency Table for LDCT Audit Forms with All LDCT Eligibility Criteria Questions Completed

\begin{tabular}{lrr}
\hline Variable & $n$ & $\%$ \\
\hline All LDCT Eligibility Criteria Questions Completed & & \\
Yes & 251 & 89.96 \\
No & 28 & 10.04 \\
$\quad$ Missing & 0 & 0.00
\end{tabular}

Note. Due to rounding errors, percentages may not equal $100 \%$.

\section{Table I4}

Frequency Table for LDCT Audit Form Questions for Determining LDCT Lung Cancer Screening Eligibility

\begin{tabular}{lrr}
\hline Variable & $n$ & $\%$ \\
\hline Is the patient $55-80$ years old? & 278 & 99.64 \\
Yes & 1 & 0.36 \\
The patient refused to answer & 0 & 0.00 \\
Missing & & \\
Is the patient a current or former smoker? & 271 & 97.13 \\
Yes & 2 & 0.72 \\
The patient refused to answer & 2 & 0.72 \\
Not answered & 4 & 1.43 \\
No & 0 & 0.00 \\
Missing & & \\
If the patient is a former smoker, did the patient quit smoking within the past 15 & \\
years? & 128 & 45.88 \\
Yes & 146 & 52.33 \\
No & 2 & 0.72 \\
Not applicable & 2 & 0.72 \\
The patient refused to answer & 1 & 0.36 \\
Not answered & 0 & 0.00
\end{tabular}

Does the patient have a pack-year history greater or equal to 30 ? 
Yes

$150 \quad 53.76$

No

$116 \quad 41.58$

Table I4 (continued)

Frequency Table for LDCT Audit Form Questions for Determining LDCT Lung Cancer Screening Eligibility

\begin{tabular}{lll}
\hline Variable & $n$ & $\%$ \\
\hline
\end{tabular}

Is the patient without signs or symptoms of lung cancer?

Not answered

$5 \quad 1.79$

Yes

$197 \quad 70.61$

No

$\begin{array}{ll}75 & 26.88\end{array}$

The patient refused to answer

$2 \quad 0.72$

Missing

$0 \quad 0.00$

Is the patient without a history of lung cancer?

No

$95 \quad 34.05$

Yes

$180 \quad 64.52$

The patient refused to answer

$2 \quad 0.72$

Not answered

$2 \quad 0.72$

Missing

$0 \quad 0.00$

The patient has not had a computed tomography (CT) of the chest within the past 11 months?

No

$112 \quad 40.14$

Yes

$161 \quad 57.71$

The patient refused to answer

$2 \quad 0.72$

Not answered

$4 \quad 1.43$

Missing

$0 \quad 0.00$

Is the patient willing to undergo treatment for lung cancer?

Yes

$218 \quad 78.14$

Not answered

$13 \quad 4.66$

No

$45 \quad 16.13$

The patient refused to answer

$3 \quad 1.08$

Missing

0.00

Note. Due to rounding errors, percentages may not equal $100 \%$. 


\section{Table I5}

Chi-square test of Observed and Expected Frequencies

\begin{tabular}{llllll} 
& \multicolumn{2}{l}{ LDCT_Orders } & & & \\
\cline { 2 - 3 } Project_Phase & Yes & No & $\chi^{2}$ & $d f$ & $p$ \\
\hline Baseline & $5[6.09]$ & $1213[1211.91]$ & 0.99 & 2 & .609 \\
Intervention & $9[6.92]$ & $1374[1376.08]$ & & & \\
Evaluation & $5[5.99]$ & $1192[1191.01]$ & & & \\
\hline
\end{tabular}

Note. Values formatted as Observed[Expected].

\section{Table I6}

Frequency Table for LDCT Lung Cancer Screening Findings

\begin{tabular}{lll}
\hline Variable & $n$ & $\%$ \\
\hline LDCT_Finding & & \\
Negative for nodule & 8 & 42.11 \\
3mm right lung, 2mm left lung & 1 & 5.26 \\
Patient did not schedule & 6 & 31.58 \\
2mm nodule right lung & 1 & 5.26 \\
5mm nodule right lung, 5mm nodule left lung & 1 & 5.26 \\
Patient did not show for test & 1 & 5.26 \\
Micro nodule right lung & 1 & 5.26 \\
Missing & 0 & 0.00 \\
\hline
\end{tabular}

Note. Due to rounding errors, percentages may not equal $100 \%$. 
